\title{
Foreign land ownership: Why are the Polish and Hungarian measures in discrimination with EU citizens' right to acquire agricultural land within the European Union?
}

\author{
Florence Humblet
}

\section{Introduction}

Property law, mainly governed by the law of the Member States (MS) is one of the most static areas of private law. For many years, the European legal order has influenced the system of property ownership to a greater extent than the popular belief has. Although the Community does not explicitly legislate on immovables, the growing European legislative body indirectly affects such property through the application of Internal Market law.'

The context of immovable property within the European Union (EU) is complicated due to the diversity among the different traditions of national law and legal systems. ${ }^{2}$ The private international law concept of lex rei sitae governs such a legal situation. This means that the applicable law is the law of the place where the immovables are located. ${ }^{3}$ Nevertheless, Internal Market rules also govern legal relations involving a cross-border element. Under those circumstances, EU law takes precedence over the application of the rules of private international law. ${ }^{4}$

Within the framework of the European Union, it might be argued that land is not of great importance because immovables are not mobile. Without a cross-border element, land remains a domestic matter. ${ }^{5}$ However the existence of a European market of land

1 Jasmina Zwierz, p. 3-4.

2 Wallis 2011, p. 26; Schmid 2005, p. 8-9.

3 Akkermans 2010, p.2.

4 Akkermans \& Ramaekers 2012, p.8.

5 Gardner 1993, p.75. 
can nowadays no longer be ignored. ${ }^{6}$ EU citizens enjoy free movement rights under the Treaties and more frequently acquire immovable property in another MS either to establish themselves, to buy a second home or to invest in that Member State.7 Free movement of persons implies a cross-border element, which is required for immovable property to be dealt with at the EU level.

This thesis focuses on the acquisition of agricultural land by foreigners - citizens of other EU Member States - in Poland and Hungary. Land is a fundamental resource of the nation state. Without land, constituting the delimitation of their territory, countries cannot exist. ${ }^{8}$ It possesses special features - e.g. limited area, economic importance, evocation of national sentiment and security - which represent much of the wealth of a state and its population. ${ }^{9}$ Because of its precious value, states have at different periods taken measures to restrict the possibility of foreigners' acquiring land within their territories. Traditionally, foreigners, categorized as non-nationals of a state, were not allowed to acquire land..$^{0}$ During the feudal period, they were seen as potential enemies to the nations. This attitude was developed and entertained by the special feudal relationship binding the people living within one territory - e.g. tenants were allowed to use their lord's land and in return they owed him services and a personal obligation of loyalty. Being free of accountableness, foreigners had no attachment to that specific land. Centuries later, the mentality towards foreigners changed. After the French Revolution, the principles of equality and fraternity were highlighted, setting citizens and foreigners on equal footing." Although this trend seems to continue, many states nowadays still restrict foreign land ownership. ${ }^{2}$ Within the European context, it can be noticed that even though free movement of persons is one of the cornerstones of the internal market, EU citizens still are sometimes confronted in real life with some infringements on their free movement rights.

Before EU Accession, the governments of Eastern and Central Europe restricted the ownership of land to foreigners. After the demise of Communism, those states turned their interests towards joining the EU. However, some conditions had to be met beforehand, one of them being the opening of their (land) market economy to EU MS nationals. This

6 Sparkes 2007, p.2.

7 Gardner 1993, p.75.

8 Hodgson et al. 1999, p.1.

9 Sparkes 2007, p. 3.

10 Sparkes 2007, p.65; Wiesman 1980, p.1.

11 Weisman 1980, p.1. 
meant the abolishment of any remaining restrictive provisions on EU citizens..$^{13}$ Poland and Hungary have experienced some difficulties, satisfying those requirements. After days of negotiation, both states obtained a transitional period of either seven or twelve years, where their existing legislation on the acquisition of agricultural land by foreigners may remain in force. ${ }^{14}$

The aim of this thesis is to examine the economical, political, social and legal frameworks behind the Hungarian and Polish transitional period. The research will answer the question:

To what extent does the status of EU citizenship, which supplements and strengthens the existing free movement of establishment, influence the Polish and Hungarian measures that are actually or potentially restricting EU citizens' right to acquire agricultural land within the European Union?

This thesis starts by introducing the Accession negotiations and general aspects concerning the conditions to be fulfilled in order to join the EU. Afterwards the transitional period will be considered within its historic and economic context. The European impact on the acquisition process will be discussed together with the interrelated relationships between the free movement of capital and the right of establishment. Then, the legal framework underlying the Polish and Hungarian situation will be presented. Finally, it will be established whether those Acts comply with EU law. For that purpose, the justifications used by Member States to explain their decisions to restrict the free movement of EU citizens will be analyzed in accordance with settled case law.

\section{Accession Negotiations}

The first step undertaken towards potential accession was the signature of association agreements, known as the Europe Agreements, between the EU and its Member States, and the Central and Eastern European countries. ${ }^{15}$ Those accords were designed to extend the

13 Williamson et al. 2002, p. 30 \& 24-43.

14 Swinnen and Vranken 2009, p.4; Annex XII of the Act of Accession (Poland), section 4.2; Annex X of the Act of Accession (Hungary), section 3.2.

Europe Agreement; Tesser 2004, p.216. 
values and practices of the Single Market to those new Member States (NMS), especially the 'four freedoms'. As regards the matter of agriculture, these Europe agreements laid down the first basis for land liberalization. ${ }^{16}$

\subsection{Accession Negotiations in general}

In 1993, the European Council met in Copenhagen and established detailed conditions to be fulfilled by those candidate states, such as stability of institutions (political criteria), functioning market economy, capacity to cope with competitive pressure and market forces within the European Union (economic criteria), and finally adoption of the acquis communautaire (acquis criteria). ${ }^{77}$ The following discussion will focus on the last two conditions.

In 1998, the EU and NMS commenced the accession negotiation process. ${ }^{18}$ The second condition of the Copenhagen criteria encompassed a functioning land market, which is opened to the EU MS nationals. ${ }^{19}$ Although Poland and Hungary had already started to remove all restrictions on EU nationals, the requirement to liberalize the land market, and particularly the agricultural land market remained a delicate matter during the discussions. ${ }^{20}$ Both candidate states raised the issue of foreign land ownership at the top of their negotiating agenda. This discussion received as much importance as the negotiation on the rate and sum of agricultural and rural subsidies (CAP). ${ }^{21}$ In Central and Eastern Europe, foreign land ownership has been a very sensitive matter and has even become a post-Cold War security concern. Lynn Tesser states the following in 2004:

"Over the course of the 1990s, foreign land ownership in East-Central Europe became what immigration is to Western Europe, a security concern that can increase support for nationalist parties." ${ }^{22}$

16 Tesser 2004, p.216; Europe Agreement (Poland); Europe Agreement (Hungary); Poland signed the Europe Agreement on 16th of December 1991. Article 44 (2) and (7) enable legal persons to acquire immovables. With regard to agricultural land, companies are allowed to lease land when it is directly necessary for the conduct of the economic activities for which they are established. The Europe Agreement relating to the Hungarian situation was signed in 1993. Companies received the same rights as in Poland (Article 44 (2) (8)). (Poland), Article 68; Europe Agreement (Hungary), Article 68.

Tesser 2004, p. 216. CAP refers to the Common Agricultural Policy. Tesser 2004, p. 214; Lynn M. Tesser is an assistant professor from the Department of Political Science, Loyola University Chicago in the United States. 
The last condition of the Copenhagen criteria related to the adoption of the Acquis Communautaire. The European Union has defined this concept as the body of common rights and obligations that bind all the Member States together within the EU. Its legal framework is not exhaustive because it constantly evolves. ${ }^{23}$ It must be noted that the 'four freedoms' are an important factor, which is enshrined in the Treaties. From the moment of their accession, Poland and Hungry have been under the duty to transpose the Acquis into their national legislation and implement it. Some derogations may be granted; however, only in exceptional circumstances. ${ }^{24}$

Because of the unsustainable tension between the highly debated land-related issues and the pressure from the EU to liberalize the land market, Poland and Hungary requested the European Commission (EC) to derogate from the freedom of capital, included within the Community Acquis, during a transitional period. The reasons highlighted by those NMS will be discussed in depth below. 25 They demanded a waiting period of 10-18 years where restrictions on EU nationals' right to acquire agricultural land in their entire respective territories would be 'tolerated' by the Internal Market rules after entry. ${ }^{26}$ At the end of the negotiations, the EC allowed them to preserve their existing restrictive legislation to a shorter transitional period. Poland obtained twelve years (until 30 April 2016) whereas Hungary received seven years (until 30 April 2011). ${ }^{27}$ An extension of three more years was later granted to the latter. ${ }^{28}$ The reasons to extend this transitional period will be further developed later. ${ }^{29}$

23 Community Acquis. The Community Acquis embraces several elements:

The content, principles and political objectives of the Treaties;

The legislation adopted in application of the treaties and the case law of the Court of Justice;

The declarations and resolutions adopted by the Union;

Measures relating to the common foreign and security policy;

Measures relating to justice and home affairs;

International agreements concluded by the Community and those concluded by the Member States between themselves in the field of the Union's activities.

24 lbid.

25 [3.2].

26 Tesser 2004, p. 4.

27 Swinnen and Vranken 2009, p. 4; Annex XII of the Act of Accession (Poland), section 4.2.; Annex X of the Act of Accession (Hungary), section 3.2.

28 Raugalaite 2012, p.55; Europa - Press releases (IP/10/1750); Europa - Press releases (MEMO/11/244); COM (2010/792/EU).

$29[3 \cdot 3]$ 


\subsection{Acquis communautaire}

\subsubsection{Supremacy of EU law}

Treaties' provisions and acts adopted by the EU Institutions before accession are binding on any new Member State after entry (Article 2 of Accession Treaty). ${ }^{30}$ The principle of supremacy of European law, included within the Acquis Communautaire, emphasizes that Community law has primacy over national law. Together with the principles of direct effect and of uniform applicability, they not only constitute the foundation of effectiveness of the Community legal order but also are potential constitutional doctrines of EU law. ${ }^{31}$ Having no formal basis in the original EU Treaties, the European Court of Justice (CJEU) has developed a broad and general doctrine of supremacy on the basis of its conception of a 'new legal order'. Nowadays, the Treaty of Lisbon establishes a Declaration on primacy. It can be deduced therefrom that EU law has always precedence. Nevertheless, it is still up to the Member States to accept and apply the primacy of EU law..$^{32}$

The European Court of Justice is entitled to interpret and apply Treaties' articles. ${ }^{33}$ The Court has enjoyed a leading role in giving prominence to the primacy principle of Community law. The CJEU recognized for the first time this highly important doctrine in Van Gend en Loos and states that the Community constitutes a new legal order of international law for the benefit of which the states have limited their sovereign rights. ${ }^{34}$ Nevertheless, the Court's primary focus in this case was to establish the direct effect of EU law on national law. Its well-known decision in Costa v. ENEL sets out the conceptual basis for the supremacy of EU law. ${ }^{35}$ The CJEU argues that the aim of creating a uniform common market between

30 As explained above [2.1], Poland and Hungary have the duty to incorporate European law into their national legal system because they joined the EU. Already at the beginning of the accession process, Poland and Hungary have been required to unify their legislation with EU standards (Article 68 of Europe Agreements (Poland and Hungary)). By signing those accords, they accept the supremacy of EU law.

31 Kwiecien 2005, pp. 1479-1480. Those principles would be regarded as constitutional doctrines of EU law if a Constitutional Treaty was established and signed by the Community.

Graig \& De Burga 2011, pp.265 \& 267; Albi 2007, p. 25; Although the Treaties still do not mention the principle of primacy, its existence and the existing case law of CJEU remain highly important.

33 Article 19 TEU: 'It shall ensure that in the interpretation and application of the Treaties the law is observed.'

34 Case 26/62 NV Algemene Transport- en Expeditie Onderneming van Gend en Loos v Nederlandse Administratie der Belastingen [1963] ECR1; Graig \& De Burga 2011, p.257. 
different states would be undermined if EU law could be made subordinate to national law of the various states. ${ }^{36}$ The principle developed in the simmenthal judgment provides national courts the ability to directly give effect to EU law and by doing so, national laws impeding the application of EU law may be either ignored or set aside. ${ }^{37}$ This means that any norms of EU law take precedence over any provisions of national law, including the national constitutions. In Dassonville, the Court emphasis that any domestic measures having a negative impact on the Internal Market should be declared as inapplicable. ${ }^{38}$

In addition to the principle of supremacy, the relationship between European law and national law encompasses two other important doctrines: the principle of sincere cooperation and the principle of subsidiarity. As regards the former, article 4(3) TEU states the following:

'Pursuant to the principle of sincere cooperation, the Union and the Member States shall, in full mutual respect, assist each other in carrying out tasks which flow from the Treaties. The Member States shall take any appropriate measure, general or particular, to ensure fulfillment of the obligations arising out of the Treaties or resulting from the acts of the institutions of the Union. The Member States shall facilitate the achievement of the Union's tasks and refrain from any measure which could jeopardize the attainment of the Union's objectives.'

European law not only prohibits restrictive measures but also allows the EU to sanction Member States that refrain from intervening when they are expected to do so. In its Spanish Strawberries judgment, the CJEU effectively follows this way of reasoning against MS passivity. 39

Set out in Article 5 TEU, the principle of subsidiarity delimits the EU competences. Although the Union may, in principle, only take action in areas falling within its exclusive competence, the EU may also act when the objectives of the proposed action cannot be sufficiently achieved by the Member States and can be better achieved at the Union level.

36 C-6/64 Flaminio Costa v ENEL [1964] ECR I- 585; Le Sueur et al. 2013, p. 817.

37 C-106/77 Amministrazione delle Finanze dello Stato v. Simmenthal SpA [1978] ECR I-629; It must be understood therefrom that the European Court of Justice does not oblige national courts to annul the conflicting national law.

38 C-8/74 Procureur du Roi v Benoît and Gustave Dassonville [1974] ECR I-00837.

39 C-265/95 Commission of the European Communities v French Republic [1997] ECR I-06959; In this case, the French government chose not to reform from intervening and to remain inactive towards the violent acts committed by French farmers against agricultural products coming from Spain. 
The second dimension of supremacy is discussed from the Member States' perspective. The Republic of Poland and the Republic of Hungary have accepted, in practice, the supremacy of EU law over national law. Having a newer Constitution, the Polish government may delegate certain competences to international organizations (Article 9o(1) of Poland's Constitution). Paragraph 2 of Article 90 specifies that those must be carried out within the limits set out in ratified international agreements. $4^{\circ}$ Importantly, Article 92 establishes direct effect and supremacy of ratified international agreements and secondary law. Contrastingly, the existing Hungarian Constitution, adopted during the Soviet period (1949), does not deal with the application of international law within its legal system. Instead, it follows a strong dualist tradition, as do other Communist Constitutions. Having no provisions on the position and applicability of international treaties, agreements must be ratified and transpose by national law. ${ }^{41}$ Judges have nevertheless undergone intensive training in EU law since the accession of Hungary to the Union. ${ }^{42}$

However, Article 8(1) of the Polish Constitution and Article $77(1)$ of the Hungarian Constitution make clear that the Constitution remain the highest source in their legal system, which limit the acceptance of the EU supremacy. Being attached to this value, the Polish and Hungarian Supreme Court have in several occasions returned favorably a verdict. ${ }^{43}$ In case of collision between Community norms and their Constitution, both Courts have nevertheless undertaken a EU approach in order to avoid, as much as possible, conflicts with European law. The Hungarian Constitutional Court follows this path in its judgment

40 Article 9o(2) states that an international agreement ratified upon prior consent granted by statute shall have precedence over statutes if such an agreement cannot be reconciled with the provisions of such statutes.

Albi 2007, p. 34

42

Ibid.; The German Constitutional Court has influenced the Hungarian Supreme Court in the methodology and style of its judicial reasoning.

In its judgment K 18/04, the Polish Constitutional Tribunal clarifies the situation by stating the following: 'The Constitution enjoys precedence of binding force and precedence of application within the territory of the Republic of Poland. The precedence over statutes of the application of international agreements which were ratified (...) in no way signifies an analogous precedence of these agreements over the Constitution.' The Court further details that, in case of collision between Community norms and the Polish Constitution, 'such a collision may in no event be resolved by assuming the supremacy of a Community norm over a constitutional norm (...)'it may not lead to situations whereby a constitutional norm loses its binding force and is substituted by a Community norm, nor may it lead to an application of the constitutional norm restricted to areas beyond the scope of Community law regulation.'; In its earlier case law, the Hungarian Constitutional Court has already expressed that the Constitution may not be amended in a disguised way by ratification of treaties (Hungarian Constitutional Court Decision 30/1998 on the Europe Agreement (VI 25) AB, Magyar Közlöny). 
on 25 of May 2004, when it declares a national implementing act unconstitutional. ${ }^{44}$ In its well know European Arrest Warrant (EAW), the Polish Supreme Court grants a period of eighteen months to modify controversial aspects. ${ }^{45}$ This strategy enables the Court to be in line with its own Constitutional as well as to respect the supremacy of EU law. ${ }^{46}$

It can be concluded that both legal systems accept the conceptual foundations that the principle of primacy is not determined by the acquis communautaire, but respectively by the Polish and Hungarian Constitutions themselves. By doing so, both legal systems retain the ultimate power to review the constitutionality of measures over the European legal framework. ${ }^{47}$ Moreover, neither Constitutional Courts accept the supremacy of European law over their Constitution. Polish and Hungarian Supreme Courts regard themselves as possessing the ultimate Kompetenz-Kompetenz. ${ }^{4}$ They are nevertheless willing to bring their legal systems into line with the demands of European law.

\section{Transitional restrictions on the acquisition of agricultural land by foreigners in Central and Eastern Member States}

The discussion under this heading will elaborate on the reasons why agricultural land received so much attention during the Accession negotiations. First, it examines the economic reasons, which mainly relate to a fear of land scarcity for domestic farmers and a

44 Decision $17 / 2004$ (V.2.5). In order to avoid further complexity and to comply with EU law, the Hungarian Constitutional Court declares that this Act dates from the pre-accession period and thereby the issue of supremacy of EU law is avoided

Graig \& De Burga 2011, p.295

46

Ibid.

47 Graig \& De Burga 2011, p. 256.

48 Graig \& De Burga 2011, p. 295; This principle establishes which court has the authority to decide on the limitation of EU's Powers. Although the CJEU has long asserted its Kompetenz-Kompetenz as the final interpreter of EU law, the Polish and Hungarian Courts have not accepted this position. Instead, those Constitutional Courts regard themselves as having the jurisdiction of the final resort to review future EU acts. Consequently, the CJEU and those Courts claim the ultimate jurisdiction to decide the limitation of EU's powers. 
dramatic difference in land prices and incomes. However, this argument does not stand by itself. Political and social reasons also deeply influenced the debate during the negotiation process. 49

\subsection{Historical context - Economic models}

During the final stage of World War II, the overwhelming Soviet Power occupied the region of Central and Eastern Europe, and imposed an economic constitution based upon Marxism. ${ }^{50}$ The concept of land ownership has since been deeply affected. Unlike the Western liberalized market, the 'means of production' were in the hands of the state and private ownership was ancient history. ${ }^{51}$ It meant that nothing belonged to anybody and a thing was defined by its own use. State enterprises produced goods and services according to the central planning - multiyear plans - established by the state. The system of contract law depreciated as it was barely used by private parties. Under those circumstances, freedom of contracts had no reason for being. Contracts were only an instrument to achieve the goals set by the state..$^{2}$ During the era of Communism, land previously individually owned was held and managed either by the state or in collective hands.53 Huge farms were therefore created except in Poland where private land ownership, in the context of small familial farms, was still tolerated. There, the pre-World War II agrarian structure was kept intact. ${ }^{54}$

After the fall of the Berlin Wall, the economic legal institutional framework had to change radically in order to rapidly liberalize emerging land and real estate markets. The previously planned economic model had to switch towards a market economy, which embraces freedom of private ownership, freedom of contract and freedom of profession and enterprise..$^{55}$ The reason for this urgent change was to avoid further impoverishment and to promote prosperity. ${ }^{56}$ The process of privatization of states' and co-operatives' lands has

49 Burger 2006, p. 573; Burger 2005, p. 2.

50 Van Erp 2006, p. 5; Williamson et al. 2002, p.33.

51 Ibid.; Private ownership was still used with regard to goods for consumption.

52 Van Erp 2006, p.5; Further information concerning the characteristics of the Communist regime can be found in Williamson et al. 2002, pp. 41-42.

53 Williamson et al. 2002, pp. 34-35; Van Erp 2006, p.5; During the Communist period, there were two types of collectivization used: full expropriation of land and property (state farms and state organization) and the consolidation of land and property into co-operatives. Dadak 2004, pp. 282-283; Williamson et al. 2002, p.33.

55 Williamson et al. 2002, pp.33 \& 42; Article 7 of the Polish Constitution (1989) guarantees the protection of personal property; Marks-Bielska 2013, p.792. Van Erp 2006, p. 5. 
been slow and land markets are generally under-functioning. ${ }^{.7}$ Mr. Miroslowa KozlowskaBurdziak gives this explanation in 2006:

According to ownership rights theory, ownership of production factors, especially land, leads to the most efficient allocation of resources. However, transforming state agriculture into private lands is not always possible due to a variety of obstacles. For example, the limited financial resources of private parties may make land purchase impossible. ${ }^{58}$

The collapse of the Soviet Union has given place to plenty of discussions by revealing the drawbacks of communism. The complete analysis of the problems arisen from this system of governance will overreach the purpose of this paper. As a consequence, two land markets Poland and Hungary - will be discussed in depth in an economic, political and social context.

\subsection{Reasoning behind the Transitional Restrictions}

\subsubsection{Economic reasons}

\subsubsection{Land market reforms}

After the fall of the Communist system, the Polish and Hungarian governments have undertaken many reforms to change their land ownership structure. Starting from 1989, land amendments pursued two main objectives: privatization of state-owned land59 and the return from cooperative to private ownership. ${ }^{60}$ The process of privatization of land and property differs depending on the particular territory. Usually, the Communist authorities pushed towards an extensive collectivization process in Central and Eastern

57 Williamson et al. 2002, p. 44. Privatization of land has resulted in the formation of very small plots of land, leading to the landscape fragmentation. Furthermore, restitution and compensation towards previous owners have been poorly performed.

58 Found in Marks-Bielska 2012, p. 792; Mr. Mirosława Kozłowska-Burdziak works at the University of Bialystok.

59 Under this type of collectivization (state-owned land), former owners were expropriated from their land and property. Consequently, the privatization process here includes the restitution or compensation of former owners for their lost.

60 Tesser 2004, p.222; Williamson et al. 2002, p.33; Under this type of collectivization, former owners' land and property were consolidated into co-operatives. Here, land and property should be restituted or compensated towards former owners. 
Europe. ${ }^{61}$ After the demise of the Berlin Wall, many former owners were willing to get back the land they had lost at the hands of the state or co-operatives. There are two processes for the restitution of property rights: restitution or compensation. ${ }^{62}$ In contrast with other Central and Eastern states, Hungary has proceeded via the process of compensation. ${ }^{63}$ By 1991, the Compensation Act I had already come into force, which compensated any Hungarian that was affected by the Communist regulations and expropriated after 1949 . Those individuals received land parcels instead of monetary compensation, parcels which were usually different from the originally owned plot of land. Later, Compensation Acts extended the circle of persons entitled to compensation. ${ }^{64}$

An exception to those methods of privatizing land markets is observable in the Republic of Poland. ${ }^{65}$ During the Communist period, farmland stayed in the hand of private farmers, meaning that Poland\$ did not experience any process of land restitution or compensation towards former owners. ${ }^{66}$ In addition to this existing private feeling, the right of ownership had been strengthened by the amendment of Article 7 of the Polish Constitution in 1989 because the Republic of Poland nowadays protects ownership and the right of inheritance, and guarantees protection of personal property. This constitutional change has modified the perception of private property in Poland. ${ }^{67}$ The Polish landscape is nevertheless not without complexities. As a result of the Potsdam Agreements after World War II, many Germans were expropriated. The Roman Catholic Church and the Polish aristocracy also lost to a large extent their lands, which were made into state farms. ${ }^{68}$

For the transformation to a free market in Poland and Hungary, it is necessary to privatize state-owned land and co-operatives. ${ }^{69}$ To fulfill that aim, the Polish and Hungarian governments respectively established the Agricultural Property Stock of the State Treasury

61 Williamson et al. 2002, pp. 33-34.

62 Ibid., p.35; Giovarelli \& Bledsoe, p. 37.

63 Former owners or their heirs have usually obtained the restitution of their land and property. This process has been since problematic due to practical difficulties (e.g. the original land parcel does not exist anymore due to the creation of roads, buildings, etc); Giovarelli \& Bledsoe, p. 37; Williamson et al. 2002, p.36.

64 lbid.

65 Giovarelli \& Bledsoe, pp. 41 \& 47; Dadak 2004, p.28o.

66 lbid.

67 Williamson et al. 2002, p.33.

68 lbid.

69 It must be kept in mind that Poland experienced little collectivization via the consolidation of land into co-operatives. 
(Poland) or the National Land Fund (Hungary). Both mechanisms are under the authority of a state institution - e.g. the Polish Agricultural Property Agency in Poland's case. ${ }^{70}$ In Poland, all liquidated collective farms and land from the original State Land Fund were incorporated into the Stock. ${ }^{11}$ In addition to this system, the Hungarian Fund bought up parcels of non-agricultural owners at real market prices and accumulated those lands. ${ }^{72}$ In the end, the majority of those plots were leased to farmers who were willing to extend their farming land on privileged terms in order to avoid disturbance in the land market. Indeed, those farmers received a pre-emptive right to buy those parcels in the future..$^{73}$

Although many efforts have been undertaken in Poland and Hungary, the land market nevertheless remains weak. ${ }^{74}$ Many factors can affect land transactions: legal restrictions, practical constraints, imperfection in other markets, high transaction costs in land markets and imperfect property rights. 75 The discussion below will mainly be about the way the population reacts vis-à-vis the privatization process. For that purpose, a short explanation on both demand and supply sides will be provided.

\subsubsection{Weak land market}

In Central and Eastern Europe, supply and demand sides of land market remain low, which does not facilitate a rapid and efficient privatization process. In general, the supply of agricultural land available on the market is limited by several factors that hinder the formation of a market economy. In Poland, the agricultural society is based upon the concept of family farms, which divides the territory in plenty of landholders holding small plots of land, usually inherited. ${ }^{76}$ Farm owners are attached to their property, as it is a symbol of security against economic problems. ${ }^{77}$ Even though most of them cannot or do not want themselves to farm, they choose to keep their lands and instead lease them to other farmers. This phenomenon seems to have had negative impact on the agrarian structure because land concentration is hampered and family distribution contributes to

70 Dz.U.z.1991 r., nr 107, poz 465 z pozn.zm; Marks-Bielska 2013, p. 792.

71 lbid.

72 Hodgson et al. 1999, p. 23.

73 lbid.

74 Burger 2006, p. 573; Giovarelli \& Bledsoe, p. 49; Dadak 2004, pp.277-278.

75 Swinnen \& Vranken 2009, p. 3.

76 Marks-Bielska 2013, pp. 797-798. Article 23 of the Polish Constitution states this concept.

77 Giovarelli \& Bledsoe, p. 49; Marks-Bielska 2013, pp. 797-798. 
the continuous fragmentation of land..$^{78}$ Furthermore, farmers are incentivized to keep their land in order to receive direct subsidy payments (CAP). ${ }^{79}$ Finally, land sale is limited due to a decrease of the amount of land owned by the State Treasury. The agrarian ownership structure seems to remain in the status quo, as the majority of land transactions concern the purchase of land by previous leaseholders. ${ }^{80}$

In Hungary, the concept of absentee ownership, being a generality, has dramatic consequences on the agricultural land market. ${ }^{81}$ After the fall of the Berlin Wall, the Hungarian government undertook initiatives to compensate former owners or their heirs even though they had mainly migrated to urban centers and did not want to farm themselves. In addition to that, farmers who remained in agriculture are now either dead or have retired. The new generation of those is not interested in agricultural land and has instead turned to other spheres of economic activity. ${ }^{82}$ Even though those Hungarians do not wish themselves to farm, they remain unwilling to sell their land due to the current low price, preferring to wait for higher prices. ${ }^{83}$

Although the financial support coming from the EU encourages Poles and Hungarians to purchase farmland, they have nevertheless shown a lack of interest in buying land demand side - due to several negative factors. ${ }^{84}$ The future of the agricultural production is first uncertain in Poland and Hungary: low profitability of agricultural production, scarce credit, mismatch of regional demand and supply, etc. ${ }^{85}$ Moreover, farmers usually prefer leasing land due to lower administrative costs. ${ }^{86}$ Nevertheless, land leasing is often a short-term form of land use. Indeed, farmers have the possibility to use a pre-emptive right, usually written in the leasing contract, which will enable them to buy land in the future. ${ }^{87}$ In Hungary, this lack of interest is also influenced by the limitation imposed on each individual wishing to acquire land up to 300 ha whereas in Poland this relates to the

\footnotetext{
78 Ibid.

79 Marks-Bielska 2013, pp. 792 \& 794; Direct subsidy payment is an instrument used by the Common Agricultural Policy.

$80 \quad$ lbid, p. 792.

81 Burger 2006, p. 573.

82 Giovarelli \& Bledsoe, p. 37.

83 Burger 2006, pp. 573- 574.

84 Dadak 2004, pp. 279-280.

85 lbid.

86 Marks-Bielska 2013, p. 794.

87 Marks-Bielska 2012, p. 796.
} 
location of land. The majority of the available territories are located in the North and West of Poland because it was previously owned by the State, which contrast with the rest of the country where private and family farm ownership has always predominated..$^{88}$

\subsubsection{Reasons elaborated during the negotiations}

During the Accession negotiations, Poland and Hungary requested the European Commission (EC) to maintain existing national provisions restricting the acquisition of agricultural land and forests by foreigners. Both governments pointed out the necessity of safeguarding their socio-economic agricultural structures from shocks arising from the differences in land prices and incomes in comparison with older Member States (OMS). ${ }^{89}$ Hungary further raised the issue of the unfinished process of privatization and restitution of agricultural land to former owners. $9^{\circ}$ This reason is of lesser importance with respect to Poland because Poland has not experienced any process of land restitution or compensation towards former owners, as explained above..$^{91}$ The Polish and Hungarian authorities mainly claimed that early removal of existing restrictions would result in unfavorable short-term outcomes, especially if foreigners acquired large portions of rural land. Following this argument, proponents of the restrictions feared a danger of land scarcity. They argue that domestic farmers would in this scenario not have sufficient land for farming. ${ }^{92}$ However, some authors disagree with this way of thinking and counterargued that the real reasons are more politically and socially oriented. ${ }^{93}$

\subsubsection{Rural nationalism - Political and Social reasons}

Nationalist parties have employed the powerful and sensitive tool of foreign land ownership to achieve their aims, which has deteriorated the situation. A particular ruralnationalist ideology emerged at the end of the $19^{\text {th }}$ century and has survived in Central and Eastern Europe, which ideology is at the core of the nationalist beliefs of today. ${ }^{94}$

88 Dadak 2004, p. 280; Swinnen \& Vranken 2009, pp. 16-17.

89 Giovarelli \& Bledsoe, p. 50; Raugalaite 2012, p.55.

90 Hodgson et al. 1999, p. 23.

91 Giovarelli \& Bledsoe, pp. 41 \& 47; Dadak 2004, p.280; As explained above [3.2.1.1.], Polish agricultural land remained during the Communist system in the hands of private farmers.

92 Burger 2005, p.3.

93 Burger 2006, p.5; Repa 2006; Raugalaite 2012, pp. 45-47.

94 Burger 2006, p. 575; Raugalaite 2012, p.45. 


\subsubsection{Rural-nationalist ideology}

At the end of the $19^{\text {th }}$ century, capitalism was seen as the cause of poverty in Central and Eastern Europe. ${ }^{95}$ Rural-nationalist partisans struggled against and wanted to end poverty. This ideology received great support from intellectuals, having generally peasant origins, thought some of them came from the gentry. ${ }^{96}$ Land-related issues are the key element of this doctrine because it does not only embody wealth but it also reflects the symbol of national being. ${ }^{97}$ Three dimensions of interest influence the concept of land. First, it incarnates the notion of 'mother earth', which belongs to nationals only and should be protected from foreigners. Secondly, representatives of this ideology support a form of anti-capitalist development where the agriculture is developed towards a small-farms scale. By doing so, large farms are suppressed and land concentration is to be prevented. Third, industrial development is to be absolutely avoided because it does not contribute to prosperity and growth. Consequently, the future of the state belongs only to the national rural farmers, who will maintain the nation..$^{8}$

In addition to this anti-capitalism sentiment, rural nationalists were against the urban intelligentsia, the majority of whom had foreign origins, because they carried out the initial development of capitalism. ${ }^{99}$ The peasant population considered them to be the evils of the nation because they were responsible for the negative features of capitalism and therefore the poverty. This strengthened the anti-capitalist feeling, which was accompanied by antipathy towards foreigners. ${ }^{100}$ In Hungary, the gentry additionally became indebted, due to an excessive luxurious lifestyle, and were therefore forced to work as low-paid employees of central and local government offices. From the Hungarian gentry point of view, foreigners, in particular Jews, were responsible for this situation because they had taken away from them the opportunities to become industrialists or bankers. ${ }^{101}$

During the two World Wars, small political parties, representing the peasantry and smallholders, took over this rural nationalist ideology to strengthen their political

\footnotetext{
95 Ibid.

96 lbid.

97 Burger 2005, p.7.

98 Raugalaite 2012, pp. 45-46; Burger 2006, p. 275; Burger 2005, p. 7.

99 Urban intellectuals were from families, belonging to citizens of former occupiers. They usually remained in the territory or it could happen that they immigrated into the country. In great majority, they were Germans and Jews.

100 Burger 2006, p. 575.

101 Burger 2005, p. 7 .
} 
beliefs. ${ }^{102}$ The Hungarian Smallholders Party spread inter alia the dogma all over and was in control of the Agriculture Ministry in the early $1920 .^{103}$

\subsubsection{Role of history}

Historical developments have influenced to a large extent the rural nationalist ideology. NMS did not experience the same economic developments as countries did in the West of Europe. ${ }^{104}$ In the $18^{\text {th }}$ century, Old Member States (OMS) carried out agricultural reforms and abolished completely feudalism and its remnants. Individual tenant farms were created and communal land was distributed among the population. ${ }^{105}$ In addition to this revolutionary event, industrialization influenced deeply the agricultural sector. Farms were quickly modernized and mechanized, having as consequences to decrease the need of labor. Under those circumstances, the agricultural population migrated to the urban areas. ${ }^{106}$ By supporting agricultural modernization, all governments established a solid legal ground for individual farming and therefore integrated this domain into the national economy. ${ }^{107}$ Consequently, the living standards of the urban classes and the agricultural population gradually became similar.

Contrary to OMS, Central and Eastern Europe not only reformed the agricultural sector much later but the industrialization also took place a century later. ${ }^{108}$ Although abolished in the mid-1 $19^{\text {th }}$ century, feudalism remained de facto enforced. The productivity was low, which did not provide enough income to the peasantry, making them much poorer than the urban population. ${ }^{109}$ In respect of state representation, the government only supported the large landowners of the ruling class, sidelining the rural population. ${ }^{10}$

Moreover, NMS experienced for years foreign occupation by such places as by Turkey, Prussia, Russia and Austria." During those periods, dramatic political changes swept the

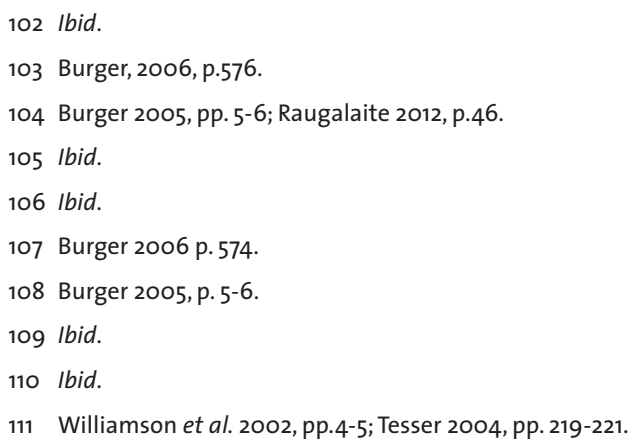


regions, which are deeply engraved in memory. It was common for inhabitants of the occupying countries to acquire large estates. ${ }^{122}$ For many years, the myth of the "German return' has circulated in Poland, creating a strong feeling against foreign land ownership. Thanks to EU expansion, Germans may be able to acquire again large amounts of land in Poland. Those acquisitions are seen as a threat against the nation.113 Contrastingly, the central issue of the political debate in Hungary is not about the threat of an unseen foreign occupation, but about a fear of a reduction of its territory as a consequence of extensive purchase of agricultural land by foreigners. ${ }^{114}$ Under this scenario, Hungary will lose its sovereignty, which is unacceptable for its population. It must be remembered that Hungary experienced in the past many modifications of the surface of its territory, leaving traces in the society.15

\subsubsection{Survival of rural nationalism}

After the demise of the Communist system, Central and Eastern governments started to restitute land towards their former owners and heirs, as explained above. ${ }^{116}$ This process differs from the privatization of the industrial sector, which was undertaken more effectively. Managers and workers were able to purchase properties whereas the former owners received small compensation. ${ }^{17}$ Political parties started to protect those new proprietors against larger farms, as inter alia claimed by the Hungarian Smallholders Party. Most of those farmers were poor, with a low level of economic growth. ${ }^{18}$ Under those circumstances, rural nationalism had all the factors to resurge.

\subsection{Mid-Term Review (2009) - Extension of the transitional period} Annexes attached to the 2003 Accession Treaty specify that the EC has to undertake a general review of the transitional measures accorded to NMS in the third year following the date of accession. ${ }^{119}$ To fulfill its duties, the Internal Market and Services DirectorateGeneral of the European Commission solicits Johan Swinnen and Liesbet Vranken to review

\footnotetext{
112 Burger 2006, p. 574 .

113 Tesser 2004, p. 218.

114 Ibid, p. 222-223.

115 Ibid.

116 [3.2.1.].

117 Burger 2005, p. 8-9.

118 Ibid.

119 Annex X of the Act of Accession (Hungary), Annex XII of the Act of Accession (Poland).
} 
those derogations. ${ }^{120}$ In their report, they argue that those restrictions have affected the efficiency of land exchanges, land allocation and productivity growth. Nevertheless, some factors have mitigated the impact such as the exceptions granted to foreigners to acquire agricultural land or the possibility to rent land. ${ }^{121}$ It must furthermore be kept in mind that several elements affect land transactions, legal restrictions being only one of those - e.g. imperfections in other markets, imperfect property rights or transaction costs. ${ }^{122}$ Foreign direct investment is to a certain extent beneficial to any economic market. Today, it is already possible to see its positive effects on certain sectors, such as the food industry, which is completely open to foreigners. Within this economic area, it is possible to notice growing productivity. ${ }^{123}$

Mr. Swinnen and Ms. Vranken secondly stress that the issues previously outlined have been dismissed even though they have not fully disappeared. Land prices and incomes have increased and are more like those in the West of Europe. However, differences can still be recognized. ${ }^{124}$ The positive aspect of the transitional period has been the change of attitude towards foreigners. In Poland, the public opinion has become more positive whereas the Hungarian population's resistance remains intact. ${ }^{125}$ In view of their analysis, Mr. Swinnen and Ms. Vranken envisage moderate changes - alternatives to the complete opening of NMS' land markets - if full land privatization remain politically too sensible or even impossible. ${ }^{126}$

Annex X, attached to the 2003 Accession Treaty, also specifies that Hungary may request a prolongation of the applicability of those transitional restrictions if there is sufficient evidence that there will be serious disturbances or a threat of serious disturbances on the

120 Swinnen \& Vranken 2009; Johan Swinnen and Liesbet Vranken are working for the Centre for European Policy Studies (CEPS), an independent policy research institute based in Brussels.

121 Swinnen \& Vranken 2009, pp. 68-70.

122 Ibid.

123 Ibid.

124 lbid.

125 lbid.; In 1999, a survey was realized and showed that $70 \%$ of the Polish population was against foreign land ownership whereas in 2004 the percentage decreased to $30 \%$. The opposition towards foreign is still today vibrant but is much less than before. In 2007, a survey revealed that more than $90 \%$ of the Hungarian public opinion are in favor of ban against foreign land ownership.

126 Swinnen \& Vranken 2009, p. 72: They suggest increasing the maximum amount of agricultural land that foreigners can acquire without restrictions. Furthermore, foreigners should be allowed to acquire farm buildings and the land on which these buildings are built without restrictions. From the authors' point of view, those proposals are beneficial for Central and Eastern Member States. 
agricultural land market after expiry of the transitional period. ${ }^{27}$ The extension is up to a maximum of three years. ${ }^{128}$ Contrastingly, Poland does not enjoy the same treatment as other NMS because this state already obtained a longer period of 12 years, which is seen as sufficient by the EC. ${ }^{129}$ On 10 September 2010, Hungary requested an extension of the period by three years. The government highlighted similar reasons as those previously outlined during the Accession negotiations. From their point of view, the Republic of Hungary still needs to buy some time in order to adjust to a market economy. ${ }^{130}$ At the end of the discussion, the EC granted this request, but nevertheless stressed the need for Hungary to speed up its efforts to progressively reform its agricultural sectors in order to prepare for full liberalization of the market. ${ }^{31}$

\section{European impact on the acquisition process}

\subsection{International context and Human Rights}

Foreign land ownership is unregulated by international law. Member States have the discretion to legislate in accordance with their own policies and requirements. ${ }^{132}$ According to customary international law, they have sovereignty over their national resources, including land, and over the entry of foreigners into their territories. Due to a high degree of discretion, states are entitled to restrict, as they please, foreigners' ability to purchase land within their territories. ${ }^{133}$

In the context of international law, legislations have been drafted to set common standards with regards to fundamental freedoms and rights. The Universal Declaration of Human Rights, proclaimed in 1948, first laid down the right to ownership. ${ }^{134}$ Later, the Convention for the Protection of Human Rights and Fundamental Freedoms was drafted,

\footnotetext{
127 Annex $X$ of the Act of Accession (Hungary), section 2.2.

128 lbid.

129 Annex XII of the Act of Accession (Poland); Nothing is mentioned in section 4 relating to the freedom of capital about a potential extension of the transitional restrictions.

130 Europa - Press releases (IP/10/1750); Europa - Press releases (MEMO/11/244); COM (2010/792/EU).

131 Raugalaite 2012, p. 56.

132 Hodgson et al. 1999, p. 2.

133 Ibid.

134 Article $17(1)$ of the Universal Declaration of Human Rights states that everyone has the right to own property alone as well as in association with others.
} 
but no guarantee was provided. It is only two years later that the right of property began to be protected, as stated in Article 1 of the First Protocol to the Convention. ${ }^{135}$ Nevertheless, it must be kept in mind that only the right to possession of property is protected, in contrast to the acquisition of immovables. In 2000, the European Community promulgated the European Charter of Fundamental Rights, establishing fundamental property rights as part of the European legal framework. ${ }^{136}$ Article 17(1) states the following:

'Everyone has the right to own, use, dispose of and bequeath his or her lawfully acquired possession. (...) The use of property may be regulated by law in so far as is necessary for the general interest.'

\subsection{European approach towards property}

According to Article 345 TFEU, formally Article 295 EC, the Treaties:

'shall in no way prejudice the rules in Member States governing the system of property ownership.'

Regarded as a 'safety clause', this Article guarantees Member States' sovereignty on matters dealing with the regulation of property. ${ }^{137} \mathrm{Dr}$. Akkermans nevertheless stresses the necessity to carefully examine the meaning of Art. 345 because its phrasing is unfortunate and its wording is so broad that the meaning becomes difficult to determine. ${ }^{138}$ At first sight, it suggests that property law is exempted from the influence of European law and remains under the discretion of MS. Following this way of reasoning, this Article might be understood as forming an obstacle for the EU to develop European property law in full or legislation in the area of property law. ${ }^{39}$

135 Sparkes 2007, p. 17; Van Erp \& Akkermans 2012, pp. 1096-1097; Article 1 of Protocol 1 of ECHR: 'Every natural or legal person is entitled to the peaceful enjoyment of his possessions. No one shall be deprived of his possessions except in the public interest and subject to the conditions provided for by law and by the general principles of international law. The preceding provisions shall not, however, in any way impair the right of a State to enforce such laws as it deems necessary to control the use of property in accordance with the general interest or to secure the payment of taxes or other contributions or penalties'

136 Sparkes 2007, p. $120-122$.

137 Jasmina Zwierz, p. 9.

138 Akkermans \& Ramaekers 2010, p. 293.

139 Ibid., p. 293-294; Sparkes 2007, p. 109. 
However, the situation seems de facto to break away from this first formal expression..$^{140}$ From a linguistic point of view, the term 'prejudice' within the negative formulation of the Article should be interpreted as without causing harm to something. ${ }^{141}$ There is therefore a difference with the first assumption. Within this context, Treaties' provisions may apply to property matters, but only as long as it does not cause harm to the national system of property ownership. It must be noticed that the rules of property ownership are left out of its scope..$^{142}$ Consequently, the EU takes a neutral stance towards the way in which MS regulate their system of property ownership, which means that the Article does not provide powers to the EU or to the Member States. ${ }^{143}$

The European institutions and the CJEU's involvements are of great relevance concerning the more practical interpretation of Art. 345. The EC has implied that the European institutions do have certain rights to interfere. National systems of property ownership remain subject to the fundamental rule of non-discrimination of the 'four freedoms', as being an inseparable part of the process of economic integration. ${ }^{144}$ The Commissioner for the Internal Market, Mr. Monti, suggests this argument when he answers the question of the MEP Mr. Watts as to whether there are any restrictions placed on the purchase of a property in EU Member States for non-nationals of that State. ${ }^{145}$

Nevertheless, the European institutions' opinion on this matter is sometimes inconsistent. In 1984, the CJEU dealt with a preliminary question brought by the Supreme Court of Ireland questioning whether an Irish Act forcing landowners to sell their land by forced sale to the Irish authorities for the purposes of increasing the size of holdings of land

140 Several decisions deliberated by the CJEU directly or indirectly have affected property law such as the Konle and the Reisch judgments. Furthermore, some existing European legislation deal with property matters - e.g. Directive 2002/47/EC of the European Parliament and the Council of 5 June 2002 on financial collateral arrangement.

141 Akkermans \& Ramaekers 2010, p. 298.

142 Ibid.

143 lbid.

144 Jasmina Zwierz, p. 10; Sparkes 2007, pp. 112-113.

145 Gardner 1993, p. 75; In 1997, MEP (Member of the European Parliament) Watts asked the Commission whether 'there are any restrictions placed on the purchase of a property in EU Member States for nonnationals of that State?' The Commissioner for the Internal Market Monti answered the following: 'While the EC Treaty in no way prejudices the system of ownership in Member States (Article 222), rules will remain subject to the fundamental rule of non-discrimination at the basis of Article 18 (discrimination), Article 45 (freedom of workers), article 49 (establishment), Article 56 (services) and measures to give effect to certain of these Articles, as well as the prohibition of all restrictions, subject to the usual exceptions, on cross border capital movements (which includes the acquisition of real estate) provided by Article 56.'This information is found in the article written by Bram Akkermans and Eveline Ramaekers (2010), p. 306. 
was in conformity with the freedom of establishment. ${ }^{146}$ The meaning of Article 222 EEC (now Art. 345 TFEU) took a central place in this proceeding. The Commission answered to this question negatively by arguing that the system of compulsory acquisition by public bodies is part of the system of property ownership in Ireland. ${ }^{147}$ To the contrary, the CJEU states:

'That conclusion cannot be accepted. By virtue of Article 54 (3)(E) of the Treaty, the restrictions on the acquisition and use by a national of one Member State are among those, which are to be abolished with a view to the realization of freedom of establishment. Similarly, the Council's 'programme general pour la suppression des restrictions à la liberté d'établissement' (General Programme for the Abolition of Restrictions on the Freedom of Establishment) of 19 December 1961 (Journal Officiel $1962, p .36)$ lists, among the restrictions on freedom of establishment to be abolished, provisions or practices which provide for less favorable rules for nationals of another Member State in regard to compulsory acquisition.

Consequently, although Article 222 of the Treaty does not call in question the Member States' right to establish a system of compulsory acquisition by public bodies, such a system remains subject to the fundamental rule of non-discrimination, which underlies the Chapter of the Treaty relating to the right of establishment. ${ }^{148}$

From those paragraphs, it can be deduced that Article 345 TFEU means to emphasize the way in which state or private ownership might belong to the MS and not how those powers are exercised. Although lawmaking competence remains under the MS's discretion, the national legislative branch must take into account the four freedoms enshrined in the Treaties. ${ }^{149}$ Further understanding of the interpretation and meaning of Article 345 TFEU will not be addressed. This heading aims to demonstrate the potential impact of European law on the domestic rules of property. Further analysis as to the applicability of the legal base will not be considered.

146 C- 182/83 Robert Fearon and Company Ltd v The Irish Land Commission [1984] ECR I-3677.

147 Found in the article written by Bram Akkermans and Eveline Ramaekers (2010), p. 309.

148 Fearon judgment, para. 6-7.

149 Akkermans \& Ramaekers 2010, p. 309; Sparkes 2007, p. 112-113. 


\subsection{European approach towards land law}

\subsubsection{Lex Rei Sitae}

European law is silent when it comes to cross-border situations relating to land issues. ${ }^{150}$ Rules dealing with land law are left to the private international law of each Member State. This area of law regulates conflict of laws, which arises when two or more legal systems come into conflict with each other. ${ }^{151}$ In circumstances of conflict of property laws, the private international law concept of lex rei sitae governs that legal situation. It means that the law applicable is the law of the place where immovables are located. ${ }^{152}$ The connecting factor here is the situs, or location, of the object of property.

Within the European Union, the context of immovables is complicated on the one hand due to diversity among the different traditions of national law and legal systems, and, on the other hand, because the EU Internal Market plays an important role where there is free movement of goods, persons, services and capital. There is an increasing tension between EU policy, the well functioning of the Internal Market and national policy, and the protection of the national legal order. ${ }^{153}$ Although national private international law applies to all cases relating to national situations, rules regulating the Internal Market also govern legal relations involving a cross-border element. In cases where EU law applies, there is supremacy of EU law over national law. In this scenario, there is therefore no room for the application of the domestic rules of private international law. ${ }^{154}$

\subsubsection{Cross-border element}

Land has geographical limits, which are fixed within the specific surface of a state. ${ }^{155}$ In the context of the European Union, it could be argued that land is not of great importance because immovables are not mobile. Without a cross-border element, land remains a domestic matter. ${ }^{156}$ However, the existence of a European market of land can nowadays no

\footnotetext{
150 Sparkes 2007, p. 97.

151 Akkermans 2012, p2-3.

152 lbid.

153 Wallis 2011 p. 26, Schmid 2005 pp. 8-9; Akkermans 2012, p.21-22.

154 Akkermans 2012, p. 8.

155 Sparkes 2007, p. 101.

156 Gardner 1993 p.75; Sparkes 2007, pp. 113-114; C-212/06 Government of the French Community and Walloon Government [2008] ECR I-3375, para. 33; C-434/og McCarthy [2011] ECR I-3375.
} 
longer be ignored. ${ }^{157} \mathrm{EU}$ citizens enjoy free movement rights under the Treaties and more frequently acquire immovable property in another MS either to establish themselves, to buy a second home or to invest in that Member State. ${ }^{158}$ This tendency is induced by several factors. First, border controls between Member States have been removed, which offers EU citizens the possibility to easily and quickly move from one Member State to another. Secondly, market players are motivated to reside in another MS due to economic reasons. Finally, air travel has become a cheap and convenient way to travel. ${ }^{159}$ The movement of those EU citizens implies a cross-border element, which is required for the matter of land to be dealt with at the EU level.

It is settled case law that EU law may not be applied to purely internal situations. ${ }^{160}$ Usually, the cross-border element must entail an actual, physical movement of the EU citizens to other MS. ${ }^{161}$ However, the CJEU has broadly interpreted this cross-border dimension. There are already citizenship cases in which the elements of true movement are either barely discernable or frankly non-existent (Gracia Avello, Zhu and Chen, Rottman). ${ }^{162}$ Advocate General (AG) Sharpston went even further by stating in Zambrano that she does not think that exercise of the rights derived from citizenship of the Union is always inextricably and necessary bound up with physical movement. ${ }^{163}$

As regards land-related issues, this current development can also be observed. It seems from case law that the CJEU has adopted a low threshold for defining the applicability of EU law, as suggested by the Flemish Decree judgment. ${ }^{64}$ The Court disagrees with the Flemish

157 Sparkes 2007 p.2.

158 Gardner 1993 p.75; Sparkes 2007, pp. 38-42; Van Erp \& Akkermans 2012, p. 1142.

159 Sparkes 2007, pp. 38-42.

160 C-434/og Shirley McCarthy v Secretary of State for the Home Department [2011] ECR I-03375; C-256/11 Dereci and others v Bundesministerium für Inneres [2011] ECR I-0oooo; C-40/11 Yoshikazu lida v Stadt Ulm [2012] not yet published.

161 C-209/03 The Queen (on the application of Dany Bidar) v London Borough Ealing \& Secretary of State for Education and Skills [2005] ECR I-02119; C-85/96 Maria Martinez Sala v Freistaat Bayern [1998] ECR I-02691.

162 C-148/o2 Carlos Gracia Avello v Belgian State [2003] ECR I-11613; C-200/02 Kunqian Catherine Zhu and Man Lavette Chen v Secretary of State for the Home Department [2004] ECR I- 09925; C-135/O8 Janka Rottman v Freistaat Bayern [2010] ECR I-01449.

163 Opinion of Advocate General Sharpston delivered on 30 September 2010 (C-34/og), para. 77.

164 Joined cases Eric Libert and Others v Government flamant (C-197/11) and All Projects \& Developments NV and Others v Vlaamse Regering (C-203/11) [2013] not yet published. 
claim saying that in this case, the situation is purely internal. ${ }^{165}$ The Court develops its line of argumentation by saying:

'It is by no means inconceivable that individuals or undertakings established in Member States other than the Kingdom of Belgium have been or are interested in purchasing or leasing immovable property located in the target communes and are thus affected by the provisions of the Flemish Decree in question. ${ }^{166}$

AG Mazak further adds that the it is clear that the decision of the referring court in such a procedure will have erga omnes effects, including on nationals of other Member States. ${ }^{167}$

\subsection{Free movement of capital}

For a long time, capital movement was sidelined compared to the strong influences of other freedoms. Although the Treaty of Rome provided for a free market in capital, it only became protected after the enactment of the Maastricht Treaty. ${ }^{168}$ Directive 88/361/EEC aimed to abolish restrictions on the free movement of capital and to liberalize the market. ${ }^{169}$ From the mid-' 90 , the achievement of the free market in capital was completed and internal frontiers were removed. ${ }^{70}$

The Treaty of Lisbon does not define the substance of capital movement; however, the CJEU provides an explanation in Luisi and Carbone: ${ }^{171}$

'Movements of capital are financial operations essentially concerned with the investment of the funds in question rather than remuneration for a service. ${ }^{172}$

$165 \mathrm{lbid}$. para. 23: 'The Flemish government claims that it is not necessary to answer those questions because, in its view, they concern only a purely internal situation quite unconnected to EU law. The actions in the main proceedings, which concern either Belgian nationals resident in Belgium or undertakings established under Belgian law, are confined within one single Member State so that the provisions of EU law relied upon are not applicable.'

166 Ibid., para. 34 .

167 Opinion Advocate General Mazak delivered on 4 October 2012 (Joined Cases C-197/11 and C-203/11), para. 23.

168 Burger 2005, p. 3.

169 Council Directive 88/361/EEC of 24 June 1988 for the implementation of Article 67 of the Treaty, L 178, 08/07/1988 P. 0005 - 0018.

170 Raugalaite 2012, p.33; Mihaljek 2005, p. 188.

171 Graig \& De Burga 2011, p. 695.

172 Joined cases (C-286/82 and C-26/83) Graziana Luisi and Guiseppe Carbone v Ministero del Tesoro [1984] ECR I-00377, para. 21. 
Under certain circumstances, the Court also refers to Annex I of Directive 88/361/EEC, where capital movement is defined as covering all the operations necessary for its purpose (conclusion and performance of the transaction and related transfers) and those operations are carried out by any natural or legal persons. ${ }^{173}$ In its judgment in Trummer and Mayer, the CJEU specifies that even though Directive 88/361/EEC is in theory not applicable anymore, the annexed nomenclature dealing with movements of capital still has the same indicative value for the purpose of defining the notion of capital movements, as it did before the entry into force of Article 73b (now Art. 63 TFEU). However, this nomenclature is not exhaustive. ${ }^{174}$

The CJEU has difficulties distinguishing between the 'four freedoms' because they frequently interrelate. In Svensson and Gustavsson, the Court analyzes the free movement of capital and the free movement of establishment, as both may be applicable at the same time, unless one of the freedoms is superior to the other in national laws. ${ }^{175}$ Initially, the CJEU accepts that national legislation is inconsistent with both freedoms. However, later, the Court specially dismisses domestic rules for infringing either free market in capital or one of the other freedoms. The Court has until now remained silent on the possibility of a 'double infringement'. In Konle, the Court recognizes that free movement of capital and free movement of establishment are applicable to the case in question. ${ }^{176}$ However, because the Court finds that there is a breach of Article 56 EC (now Art. 63 TFEU), it does not further analyze the freedom of establishment. Curiously, AG La Pergola adopts the opposite approach in this case. ${ }^{177}$ It can be concluded from the judgment and from the

173 C-464/98 Westdeutsche Landesbank Girozentrale v Friedrich Stefan [2001] ECR I-173, para 5; Article 1 Dir. 88/361/EEC: '(1) Without prejudice to the following provisions, Member States shall abolish restrictions on movements of capital taking place between persons resident in Member States. To facilitate application of this Directive, capital movements shall be classified in accordance with the Nomenclature in Annex I. (2) Transfers in respect of capital movements shall be made on the same exchange rate conditions as those governing payments relating to current transactions.'; Article 63 (Article $73 \mathrm{~b}$ at the time) reproduces the contents of Article 1 of Council Directive 88/361/EEC'.

174 C-222/97 Proceedings brought by Trummer and Mayer [1999] ECR I-1661, para. 21.

175 C-484/93 Peter Svensson and Lena Gustavsson v Ministre du Logement et de I'Ubanisme [1995] ECR I03955 .

176 C-302/97 Konle v Austrian Republic [1999] ECR I-3099, para 22.

177 Opinion Advocate General La Pergola delivered on 23 February 1999 (C-302/97); Advocate General La Pergola is in the opinion that the free movement of establishment is of primary importance in this case to the contrary of the free movement of capital. For that reason, AG La Pergola will go further in analyzing the right of establishment to the particular case. 
opinion in Konle that both freedoms may apply in parallel to one another. ${ }^{178}$ The following part of this paper will explain more in depth the close relationship between the provisions on free movement of capital and those on free movement of persons in the form of the free movement of establishment, and the reasons why restrictions on the free movement of capital may affect the right of establishment.

\section{Free movement of persons}

\subsection{European citizenship}

The Treaty of Maastricht introduces the legal concept of European citizenship; a novel and complementary status for all MS nationals. ${ }^{179}$ Article 20 TFEU summarizes its main elements, in which EU citizenship is defined as being additional to national citizenship and contingent upon possession of one MS nationality. ${ }^{180}$ Enshrined in Article 21 TFEU, the rights of free movement and residence of EU citizens are an essential political symbol and a milestone of the Internal Market. Directive 2004/38 defines the personal scope of free movement of persons and how those people should be treated in another MS. EU citizenship has generally expanded and strengthened existing rights of movement, residence and non-discrimination. ${ }^{181}$

178 lbid.

179 Graig \& De Burca 2011, p. 819.

180 Article 20 TFEU: '(1) Citizenship of the Union is hereby established. Every person holding the nationality of a Member State shall be a citizen of the Union. Citizenship of the Union shall be additional to and not replace national citizenship. (2) Citizens of the Union shall enjoy the rights and be subject to the duties provided for in the Treaties. They shall have, inter alia: (a) the right to move and reside freely within the territory of the Member States; (b) the right to vote and to stand as candidates in elections to the European Parliament and in municipal elections in their Member State of residence, under the same conditions as nationals of that State; (c) the right to enjoy, in the territory of a third country in which the Member State of which they are nationals is not represented, the protection of the diplomatic and consular authorities of any Member State on the same conditions as the nationals of that State; (d) the right to petition the European Parliament, to apply to the European Ombudsman, and to address the institutions and advisory bodies of the Union in any of the Treaty languages and to obtain a reply in the same language. These rights shall be exercised in accordance with the conditions and limits defined by the Treaties and by the measures adopted thereunder.'

181 Directive2004/38/EC du Parlement Européen et du Conseil du 29 avril 2004 relative au droit des citoyens de l'Union et des membres de leurs familles de circuler et de séjourner librement sur le territoire des États membres, modifiant le règlement (CEE) no 1612/68 et abrogeant les directives 64/221/CEE, 68/360/CEE, 72/194/CEE, 73/148/CEE, 75/34/CEE, 75/35/CEE, 90/364/CEE, 90/365/CEE et 93/96/CEE. 
Traditionally, the personal scope of freedom of movement is restricted to the so-called 'market citizenship'. It reflects the classic, economic rights to free movement, which means that EU citizens must be economically active in order to enjoy those rights - e.g. workers, self-employed persons or a service recipient. ${ }^{182}$ However, the 'sector-by-sector approach' is slowly and carefully moving in the direction of a 'EU citizen approach', as suggested by AG Sharpston in Zambrano. ${ }^{183}$ Article 20 TFEU creates autonomous and directly effective rights to move and reside in any MS, as suggested in Baumbast. ${ }^{184}$ By granting those rights to every citizen, the Treaties recognize the principal role of individuals, irrespective of whether or not they are economically active. In Grzelczyk, the CJEU states the following:

'Union citizenship is destined to be the fundamental status of nationals of the Member States enabling those who find themselves in the same situation to enjoy the same treatment in law irrespective of their nationality, subject to such exceptions as are expressly provided for. ${ }^{185}$

From the point of view of AG Sharpston in Zambrano, this statement is of similar significance as the CJEU's seminal statement in Van Gend en Loos that 'the Community constitutes a new legal order of international law for the benefit of which the States have limited their sovereign rights (...) and the subjects of which comprise not only Member States but also their nationals. ${ }^{186}$

Nevertheless, its must be noticed that free movement rights cannot, even today, be separated from the traditional economic rights to freedom of movement. Although noneconomically active EU citizens are now allowed to enjoy rights of movement and residence, the status of EU citizenship still remains largely supplemental and residual to the economic status of workers or self-employed persons. ${ }^{187}$ Under certain instances, such as matters of social and material benefits, reliance on this status is less beneficial to EU citizens than reliance on another status category. Consequently, EU citizenship cannot be given solely and

182 Graig \& De Burca 2011, p. 824 .

183 Opinion of Advocate General Sharpston delivered on 30 September 2010 (C-34/og).

184 C-413/99 Baumast and R v Secretary of State for the Home Department [2002] ECR I-07091, para. 94.

185 C-184/99 Rudy Grzelczyk v Centre Public d'aide social d'Ottignie - Louvain-la-Neuve [2001] ECR I-o6193, para. 31 .

186 C-26/62 NV Algemene Transport- en Expeditie Onderneming van Gend \& Loos v Netherlands Inland Revenue Administration [1963].

187 Graig \& De Burca 2011, p. 847. 
free movement of workers, services and establishment remain of great relevance. ${ }^{188}$ It is the reason why the right of establishment will also be analyzed in this paper.

\subsection{Right of establishment in relation with the free movement of capital}

Although the purchase of immovable property is usually dealt within the scope of free movement of capital, this freedom is closely related to the right of establishment. ${ }^{189}$ This is clearly apparent from the reciprocal reservations contained in Article 49 and 65 TFEU. Furthermore, the CJEU recognizes in its Greek Border Regions judgment that selfemployed persons possess a corollary right to freely acquire immovable property within the European Union. ${ }^{90}$ Nowadays, this right is laid down in Article 5O TFEU. ${ }^{191}$ AG Geelhoed further elaborates in Reisch this line of reasoning:

'It does not follow from the annex that every acquisition of immovable property is governed by the free movement of capital, but it does follow that an investment, in, or speculation with, immovable property may come under the free movement of capital. What is decisive is the activity to which the domestic legislation relates. Is it the acquisition of immovable property with the aim of using it in a given way, or is it the investment?'192

Such a close relationship has been problematic in practice, especially for cases of transactions involving immovable property. The Court has experienced difficulties

188 lbid.

189 The right of establishment is laid down in Article 49 TFEU: 'Restrictions on the freedom of establishment of nationals of Member State in the territory of another Member State shall be prohibited.' EU citizens evoked within this heading are economically active individuals that do not fall under the definition of worker.

190 Case 305/87, Commission v Greece [1989] ECR 1461, para. 22: 'In particular, as is apparent from Article 54(3)(e ) of the [EEC] Treaty and the General programme for the abolition of restrictions on freedom of establishment of 18 December 1961 (Official Journal, English Special Edition, Second Series IX, p .7), the right to acquire, use or dispose of immovable property on the territory of a Member State is the corollary of freedom of establishment.'; C-302/97 Konle v Austrian Republic [1999] ECR I-3099, para. 22.

191 Van Erp \& Akkermans 2012, p. 1092; Art. 50(2)(e) TFEU: '(...) by enabling a national of one Member State to acquire and use land and buildings situated in the territory of another Member State, in so far as this does not conflict with the principles laid down in Article 39(2).'

192 Opinion of Advocate General Geelhoed delivered on 20 November 2001 (C-515/99, C-519/99 to C-524/99 and C-526/99 to C-540/99), para. 43. 
differentiating the free movement of capital and of establishment. ${ }^{193}$ In Baars, AG Alber develops a line of reasoning which helps distinguish both freedoms in particular cases.

'Where the free movement of capital is directly restricted such that only an indirect obstacle to establishment is created, only the rules on capital movements apply. Where the right of establishment is directly restricted such that the ensuing obstacle to establishment leads indirectly to a reduction of capital flows between Member States, only the rules on the right of establishment apply."194

However, there are situations where both are applicable in parallel, such as in Konle concerning the purchase of land for residual purposes in another MS. For such cases, AG Alber further explains:

'Where there is direct intervention affecting both the free movement of capital and the right of establishment, both fundamental freedoms apply, and the national measure must satisfy the requirements of both."195

From AG Alber's point of view, cases involving 'direct intervention' apply where prohibition on the purchase of land for residual purposes is directly restricting the right of establishment and the free movement of capital on the basis that the purchase of land always represents an investment of capital. ${ }^{196}$ Under those circumstances, it must be noticed that national measures restricting free movement of capital do not per se infringe upon the right of establishment. However, in the apposite situation, both freedoms are constrained.

Although AG Geelhoed follows this line of reasoning in Reisch, he shifts the emphasis. ${ }^{197}$ From his point of view, the acquisition of immovable property should be the point of departure rather than should the investment or the transfer of capital because the Austrian legislation does not restrict EU citizens from investing capital in immovable property as such. Its purpose is to regulate the use of immovable property as secondary residences. ${ }^{198} \mathrm{AC}$

\footnotetext{
193 [4.4]

194 Opinion of Advocate General Alber delivered on 14 October 1999 (C-251/98), para. 26.

195 Ibid., para 30.

196 Ibid., para $28 \& 29$.

197 Opinion of Advocate General Geelhoed delivered on 20 November 2001 (C-515/99, C-519/99 to C-524/99 and C-526/99 to C-540/99), para 63.

198 lbid.
} 
Geelhoed further defines the concept of acquiring immovable property, which is of central relevance for this paper.

'The acquisition of immovable property involves, by definition, a capital transaction. This capital transaction is used to pay for the immovable property or is linked to the financing of the transaction. Moreover, the acquisition of immovable property, and of other capital goods, differs from the acquisition of consumer goods. The acquisition of immovable property and of other capital goods always has an element of investment. After its acquisition, the property forms part of the acquirer's assets. ${ }^{199}$

As it can be understood from this paragraph, the capital transaction is not the main element; rather, it is secondary. AG Tesauro follows this way of thinking in his Opinion in Safir.

'The restriction of the movement of capital is only indirect, and the measure primarily constitutes a non-monetary restriction on the freedom to provide services. ${ }^{200}$

Capital transactions are regarded no more highly than any other payments made for a service provided. For that purpose, the CJEU's judgment in Luisi and Carbone should be highlighted. In this case, the Court draws a distinction between current payments and the movement of capital.

'(...) Current payments are transfers of foreign exchange which constitute the consideration within the context of an underlying transaction, whilst movements of capital are financial operations essentially concerned with the investment of the funds in question rather than remuneration for a service (...).'201

In his Opinion in Reisch AG Geelhoed argues that the capital transaction involved should be regarded as remuneration for a service. Even though capital transactions underlying the acquisition of immovable property is more complex than those of movable goods, the

199 lbid.

200 Opinion of Advocate General Tesauro delivered on 23 September 1997 (C-118/96), para. 17.

201 Joined cases (C-286/82 and C-26/83) Graziana Luisi and Giuseppe Carbone v Ministero del Tesoro [1984] ECR I-00377, para. 21. 
former always includes an element of investment. ${ }^{202}$ However, AG Geelhoed specifies the following:

'This does not in itself mean that the emphasis is placed on the free movement of capital (...) the provisions of the Salzburger Grandverkehrsgesets of 1997 are aimed at economic activities to which the freedom to provide services applies. There is no more than an indirect relationship with the free movement of capital.' ${ }^{203}$

This line of reasoning is relevant for the free movement of establishment. With respect to transactions of immovable property, freedom to move certain types of capital is de facto a pre-condition for the effective exercise of other freedoms guaranteed by the Treaties, in particular the right of establishment, as suggested by the CJEU in Casati. ${ }^{204}$

\section{Transitional restrictions originating from the freedom of capital - applicable to the movement of persons}

\subsection{Legal framework}

During the Accession negotiations, Poland and Hungary obtained a transitional period, where their existing legislation on the acquisition of agricultural land by foreigners may remain enforced. ${ }^{205}$ Within these two legal orders, different conditions apply as to whether the acquirer is a foreigner (EU citizen) or a Polish national. After 2016 (Poland) and 2014 (Hungary), citizens of the European Union will be allowed to purchase agricultural land without any further restrictions, while the requirements laid down in the Act of 24 March 1920 and the Act LV of 1994 will remain effective for foreigners from outside the European Union. ${ }^{206}$

202 Opinion of Advocate General Geelhoed delivered on 20 November 2001 (C-515/99, C-519/99 to C-524/99 and C-526/99 to C-540/99), para 73.

203 lbid.

204 C- 203/80 Criminal proceedings against Guerrino Casati - Reference for a preliminary ruling: Tribunale civile e penale di Bolzano [1981] ECR I-02595, para. 8.

205 [2.1.]; With regards to the Polish legal system, the relevant legislation is the Act of 24 March 1920 on the Acquisition of Immovable property by Foreign persons, whilst the Act LV of 1994 on Arable land is applicable in Hungary.

206 Ciaian et al. 2012, p. 10; Europa - Press releases (IP/10/1750); Europa - Press releases (MEMO/11/244). 


\subsubsection{The Polish legal system}

\subsubsection{Statutory law}

Traditionally, private international law was applicable to cases involving foreigners willing to purchase Polish agricultural land. According to Article 25(2) of the Act of 12 November 1965 on Private International Law, the principle of lex rei sitae - the law of the location of the property - applied to those issues. Since the accession of Poland into the European Union, European Treaties and agreements are superior to this Act. The Polish legal order was substantially amended in order to implement the terms of the Treaties. ${ }^{207}$

\subsubsection{Act of 24 March 1920 - Prior authorization procedure}

Under Polish law, sales to foreigners are as such not totally restricted. The acquisition of agricultural land is subject to a specific procedure whereby both the Ministry of Interior and Administration, and the Ministry of Agriculture and Rural Development, need to grant their permission. ${ }^{208}$ Nowadays, the Act has been amended and both ministries are no longer able to give their consent. Instead, they are empowered to lodge an objection ('silent consent') in order to restrain sales. ${ }^{209}$

This procedure not only applies to natural persons without Polish citizenship, but also to legal persons: companies based abroad, companies based in Poland but controlled by natural persons not having the Polish citizenship, or partnerships of both. ${ }^{210}$ The documents attached to the application for the permit comprise plenty of specific information (Article 1a(3)): (1) the designation of the applicant and his legal status, (2) the particular immovable property of the undertaking, (3) the seller, (4) the legal status of the acquisition of immovable property and finally (5) the information on the purpose and possibility of acquisition of real estate.

Initially, it must be noted that there was no specific basis on which permission should be granted. The ministries had a high degree of discretion. ${ }^{211}$ Later, some criteria emerged and were laid down in Article 1(a) of the Act. The acquisition first may not pose threat to the defense, national security or public order, and should be not in contradiction with

207 The Act of 24 March 1920 was amended by the Act of 20 February 2004 on the amendments to the Act on the Acquisition of Immovable Property by Foreign persons.

208 Article 1(1) of the Act of 24 March 1920 on the Acquisition of Immovable property by Foreign persons.

209 Jasmina Zwierz, p. 12.

210 Article 1(2) of the Act.

211 Tesser 2004, p.5. 
social policy and public health considerations. This requirement provides some flexibility to the ministries. Secondly, foreigners have to prove some ties with the Republic of Poland, which is exemplified in the second paragraph: Polish nationality or origin, Polish spouse, possession of a permanent resident status ( 5 years), or continuing business and agricultural activity in Poland. The last paragraph of Article 1 also shows the possibility to additionally restrict the system. The agricultural property agency has a pre-emptive right to purchase the land that was offered for such a transaction, a right laid down in Article 1(6), which refers to Article 3(4) of the Act of formation of the agricultural system.

Besides the traditional requirements, the Minister of Interior and Administration may request additional conditions, which only the satisfaction of which will determine the receiving of this special permission. ${ }^{212}$ To make the situation even more complex, this minister may also encourage bodies of public administration, professional organizations and states institutions to express their opinions and even transfer documents and information, in particular those contained in the records of land and buildings, which may be essential to the satisfaction of the conditions. ${ }^{213}$ In cases where such a permit is obtained on the basis of Article 3, it is valid for two years from the issuance thereof. This period of time was extended by amendments, which protect better the interests of the parties involved. ${ }^{214}$

\subsubsection{Exemptions}

In 1996, amendments were introduced due to EU membership requirements, specifying that a permit is not required under certain specific instances. ${ }^{215}$ Article 7(3) of the Act states inter alia that inheritance under a testament may be excluded from permit requirement. It must nevertheless be stressed that plots of land located in border zones and parcels of agricultural land exceeding one hectare are excluded from those exemptions (Article 8(3)).

Foreigners can acquire agricultural real estate if they are residing for at least five years in Poland, ${ }^{216}$ and if they are married to a Polish citizen and residing for at least two years in Poland. In addition, such acquisition must constitute the joint property of wife and

\footnotetext{
212 Article 2(2) of the Act.

213 Article 2(a) of the Act.

214 Jasmina Zwierz, p. 13.

215 Article 8 of the Act.

216 A foreigner must nevertheless prove that she/he possesses a stable source of income for maintenance of the property and his family. Furthermore, he must own an adequate health insurance.
} 
husband. ${ }^{27}$ Furthermore, even though there is a transitional period of twelve years before purchasing agricultural land, EU citizens specially do not need to obtain a permit if the they have rented the land for at least three years in the regions of Lubelskie, Łódzkie, Małopolskie, Mazowieckie, Podkarpackie, Podlaskie, Śląskie, Świętokrzyskie Voivodeships, or for seven years in the regions of Dolnośląskie, Kujawsko-Pomorskie, Lubuskie, Opolskie, Pomorskie, Warmińsko-Mazurskie, Wielkopolskie, Zachodnio-Pomorskie Voivodeships. ${ }^{218}$ In addition to that, the rental contract has to contain a certified date and foreigners should have personally used the land for agricultural production and have stayed legally in Poland. ${ }^{19}$

\subsubsection{The Hungarian legal system}

\subsubsection{Act LV of 1994 - law banning foreign acquisition of land}

Between 1989 and 1994, the Hungarian government did not ban the acquisition of arable land - agricultural land for the purpose of this paper - by foreigners. Like in Poland, sales to foreigners were subject to a specific procedure whereby authorities' permission was required and often easily granted. ${ }^{220}$ Many Austrians profited from this godsend and purchased agricultural land in great quantity, which were significantly cheaper than in Austria. ${ }^{221}$ However, from 1994, the Hungarian government took things over and implemented the Act LV of 1994 on Acquisition of Ownership of Arable Land, a law banning foreign acquisition of land (Section 7). ${ }^{222}$ Legal restrictions forbidding foreigners from acquiring agricultural land not only apply to natural persons without Hungarian citizenship but also to legal persons, companies based abroad or the unincorporated organization having such a seat. ${ }^{223}$ In respect of the ability of legal persons to acquire agricultural land, the Hungarian legal order is very strict because this restriction also applies to domestic legal entities (Section 6).

\subsubsection{Exemptions}

Like Poland, Hungary amended the Act LV of 1994 in order to fulfill EU membership requirements. Some exemptions to the law banning acquisition of agricultural land by

\footnotetext{
217 Ciaian et al. 2012, p. 11.

218 lbid.

219 Swinnen \& Vranken 2009, p.1758.

220 Article 1(1) of the Act of 24 March 1920 on the Acquisition of Immovable property by Foreign persons.

221 Tesser 2004, pp. 222-223.

222 Ibid.

223 Section 3(2) and (3) of the Act.
} 
foreigners were developed in favor of EU citizens. In respect of the acquisition of nonagricultural land, EU citizens have become subject to the same rules and provisions as those that apply to Hungarian nationals. ${ }^{224}$ However, the situation concerning arable land is far more complex.225

EU citizens may first acquire arable land if they are married to a Hungarian citizen, as it is the case in Poland. ${ }^{226}$ Then, they are allowed to do so if they want to establish themselves as self-employed farmers, and have been legally staying and farming in Hungary continuously for at least three years. The limit on the amount of land is similar to that of domestic private persons (300 ha). ${ }^{227}$ In this scenario, foreign and domestic acquirers have a right of preemption. With respect to a protected nature area, the Hungarian State is also entitled to the right of pre-emption, which precedes the right of those beneficiaries. ${ }^{228}$

Finally, foreign nationals may acquire ownership of a homestead formed as an independent real property (parcel of land) of 600om or less, in accordance with the rules of specific other legislation on other properties not classified as arable land. ${ }^{229}$ It must be noticed that a homestead is in nature different from arable land. Arable land is defined as a plot of land, that is registered in the outskirts of a settlement in the land register and more specifically in the branch of cultivation of plough-land, vineyard, orchard, meadow, reeds and forest or as fish-pond; in contrast of a homestead is recognized as being a complex of dwelling and economic buildings, together with a group of buildings built in the outskirts of the settlement with the purpose of agricultural production (plant cultivation and animal husbandry, as well as the related processing of products and storage of produces) and of the land belonging thereto under an identical topographical lot number (Section $3(a)$ and (b)).

EU nationals must nevertheless fulfill one requirement: they must provide proof of eligibility. It means that they have to obtain the following document: an official certificate issued by the immigration authority, which certifies the existence of a permanent residence permit or an authorization to reside in the territory. EU citizens must additionally own a certificate from the county agricultural bureau, which certify that the private person has been engaged in agricultural activities in Hungary. ${ }^{230}$

\footnotetext{
224 Ciaian et al. 2012, p. 10.

225 Ibid; Hodgson et al. 1999, p.25.

226 Swinnen \& Vranken 2009, p. 5.

227 Section 5(1) of the Act.

228 Section 10 of the Act.

229 Section $5(3)$ and 8 of the Act.

230 Swinnen \& Vranken 2009, p. 10.
} 


\subsection{Are those restrictions discriminatory?}

\subsubsection{The Internal Market}

The European Union is built upon the principle of an open market economy with free competition, as laid down in Article 3(3) TEU.231 The Community has developed an Internal Market as a tool to achieve one of its main goals: the promotion of economic prosperity. The Treaties provide the legal framework towards further economic integration, which is called 'Wirtschaftsverfassung' or economic constitution by the German literature. ${ }^{232}$ Having fundamental rights as cornerstones, the ideology behind this concept can be traced back to the French Revolution. Following the ideals of 'Freedom, Equality and Fraternity', free citizens are equal to all other free citizens and private ownership takes a place of central importance. 'Without private ownership, a free market economy based upon free competition is not possible. The fundamental right to private ownership plays, therefore, a dominant role in the European Economic institution.'233

Within the Internal Market framework, the basic economic purpose of the free movement rules is the optimal allocation of resources for the European Union. ${ }^{234}$ As regards land law, it encompasses a functioning land market, including agricultural land, which is open to the EU MS nationals. ${ }^{235}$ The Internal Market is about the simplification and enhancement of the legal framework, positive integration, and the elimination of remaining obstacles, negative integration, in order to optimize the opportunities of any EU citizen within the European Union. ${ }^{236}$ This paper concentrates on the concept of removing barriers as being the classic way in which the 'four freedoms' operate.

Article 26 TFEU lays down the legal basis that European law prohibits any national rules that hinder cross-border trade (negative integration). Domestic provisions restricting free movements across the EU will be seen either as directly discriminatory against one of the 'four freedoms' or indirectly discriminatory, whether or not those rules render market access more

231 Article 3 TEU:'The Union shall establish an internal market. It shall work for the sustainable development of Europe based on balanced economic growth and price stability, a highly competitive social market economy, aiming at full employment and social progress, and a high level of protection and improvement of the quality of the environment. It shall promote scientific and technological advance.'

232 Van Erp 2006, p.4.

233 lbid.

234 Graig \& De Burca 2011, p.715.

235 Williamson et al. 2002, pp 30 \& 42-43.

236 Graig \& De Burca 2011, p.582. 
difficult. ${ }^{237}$ Discrimination may only be found either where two comparable groups are treated differently or where groups, which not comparable, are treated in the same way. This approach is strengthened by the principle of mutual recognition, which has as aims to facilitate market access in other Member States. ${ }^{238}$

The previous headings of this paper attempted to explain in depth the economical, social, political and legal frameworks behind the transitional periods granted to Poland and Hungary. The last parts will analyze whether or not the Act of 24 March 1920 and the Act LV of 1994 are in compliance with EU law. At this stage, it must be noticed that the CJEU has rarely returned a verdict concerning the acquisition of agricultural land. The matter is usually associated with the market of secondary residence. ${ }^{239}$ Therefore, case law dealing with the acquisition of immovable property in general and of secondary residence are of high relevance to the matter because it shows the Court's point of view on purchasing immovables in other Member States.

\subsubsection{Discrimination principles}

In respect of land-related issues, capital is seen as secondary to the right of establishment because the payment will be only used to buy the agricultural land. It arises therefrom that within this context, the right of establishment cannot stand by itself. Free movement of capital and free movement of establishment are concurrent and both should be interpreted, even though the Court usually only analyzes the movement of capital. ${ }^{240}$ In this paper, the Polish and Hungarian existing provisions will only be interpreted according to Art. 21 and Art. 49 TFEU. The CJEU points out in its Flemish Decree judgment the discrimination principles in relation to those two Articles:

'(...) Article 21 TFEU and, in the respective area, Article 49 TFEU prohibit national measures which preclude or deter a national of a Member State from leaving his country of origin in order to exercise his right to freedom of movement within the European Union. Such measures, even if they apply without regard to the nationality of the individuals concerned, constitute restrictions on the fundamental freedoms guaranteed by those articles. ${ }^{241}$

237 Ibid.

238 lbid.; Established by the CJEU in Cassis de Dijon, products lawfully marketed in one MS should be allowed to be marketed in any other MS.

239 C-302/97 Konle v Austrian Republic [1999] ECR I-3099; C-423/98 Albore [2000] ECR I-5965; Joined cases (C-515 and 527-540/99) Reisch v Bürgermeister der Landeshauptstadt Salzburg [2002] ECR I-2157.

240 [5.2.]; C-302/97 Klaus Konle v Austrian Republic, [1999] ECR I-03099; Joined cases (C-515/99, C-519/99 to C-524/99 and C-526/99 to C-540/99) Reisch and others v Burgermeister der landeshauptstadt Salzburg, [2002] ECR I-2157.

241 Joined cases (C-197/11 and C-203/11) Eric Libert and others v Government flamand and All projects \& developments NV and others v Vlaams Regering, [2013] not yet published, para. 38.

Foreign land ownership: Why are the Polish and Hungarian measures in discrimination with EU citizens' right to acquire agricultural land within the European Union? 
During the transitional period, the applicable law regulating the matter of acquiring farming land in Hungary is very extreme in its way of functioning. Section 7 of Act LV of 1994 totally bans foreign acquisition of arable land. Such measure applies with regard to the nationality of the individuals concerned because non-Hungarian citizens are forbidden to acquire land in Hungary. It follows undoubtedly that the Act LV of 1994 is directly discriminatory on the fundamental freedoms guaranteed by Art. 21 and Art. 49 TFEU on grounds of nationality.

Contrastingly, the Polish government allows foreigners to purchase agricultural land in Poland. Nevertheless, different conditions apply depending on whether the acquirer is a Polish citizen or a national from another Member State. Article 1(1) of the Polish Act requires foreigners to obtain a permit before acquiring agricultural land. In relation to the free movement of capital, the CJEU has already declared that the obligation to submit to such a prior authorization procedure constitutes an indirect restriction on the capital movement because it is likely to discourage non-residents or non-nationals from making investments in immovable property in the Member State in question. ${ }^{242}$ Consequently, the Act of 24 March 1920 is indirectly discriminating the rights to movement, residence and establishment because obtaining a permit is more easily satisfied by Polish nationals than by non-nationals.

Annexes X and XII of the Accession Treaty specify that the existing Hungarian and Polish provisions regulating the process of land acquisition by foreigners may only remain enforce in accordance with the free movement of capital. ${ }^{243}$ In respect of the other three freedoms, nothing is specifically written down in this Treaty. By affecting the acquisition of immovable property, restrictions on the free movement of persons, such as those in Poland and Hungary, are not totally exempted from the influence of EU law during the transitional period. The second paragraphs of Annex X and Annex XII further stress that MS nationals may in no instance be treated less favorably in respect of the acquisition of agricultural land and forest at the date of signature of the Accession Treaty. ${ }^{244}$ By effectively infringing upon the European legal order, this situation has become untenable and changes must be undertaken.

242 Ibid., para. 47; C-302/97 Klaus Konle v Austrian Republic, [1999] ECR I-03099, para. 23-24; Joined cases (C-515/99, C-519/99 to C-524/99 and C-526/99 to C-540/99) Reisch and others v Burgermeister der landeshauptstadt Salzburg, [2002] ECR I-2157, para. 32.

243 Look at Annex X (section 3) and Annex XII (section 4) of the Accession Treaty.

244 Section 4.2. of Annex X of the Accession Treaty (Hungary) and Section 3.2. of Annex XII of the Accession Treaty (Poland). 
National measures, which are liable to hinder or make less attractive the exercises of fundamental freedoms, in particular the free movement of establishment, may nevertheless be allowed, provided that they pursue either an objective on the grounds of public policy, public security or public health laid down in Article 52 TFEU (direct discrimination) or an objective in the public interest (indirect discrimination), as suggested in Gebhard. ${ }^{245}$ National measures must further fulfill the principle of proportionality. This means that national measures must be suitable for securing the objectives pursued and must not go beyond what is necessary in order to attain them. ${ }^{246}$ The Court follows this approach in Reisch and explains the following:

'Restrictions may be permitted if the national rules pursue, in a non-discriminatory way, an objective in the public interest and if they observe the principle of proportionality, that is if the same result could be achieved by other less restrictive measures. ${ }^{247}$

\section{Justification process - Legitimate grounds and the proportionality test}

\subsection{Legitimate grounds}

\subsubsection{Public policy and Public security}

In respect of the justification process, the main issue concentrates on the status of private individuals because legal entities are treated on the same footing as domestic companies. In Hungary, neither is allowed to acquire arable land. ${ }^{248}$ In the event of direct discrimination, Article 52 TFEU provides three types of legitimate grounds, but, only two of them are relevant to the Hungarian situation: public policy and public security.

In relation to land-related issues, public security is, in principle, available in the form of military justification, as suggested in Albore and in the Greek Border Regions case. In Albore,

\footnotetext{
245 C-55/94 Reinhard Gebhard v Consiglio dell'Ordine degli Avvocatie Procuratori di Milano ECR I-04165, para. 37 .

246 lbid.

247 Joined cases (C-515/99, C-519/99 to C-524/99 and C-526/99 to C-540/99) Reisch and others v Burgermeister der landeshauptstadt Salzburg, [2002] ECR I-2157, para. 33.

248 Section 6 and 7 of the Hungarian Act.
} 
the Italian legislation requires an administrative authorization for any purchase of real property in an area of the country designated as being of military importance; similarly, Greece applies the same regime to all land in the Greek border regions, comprising about 55 per cent of Greek territory. ${ }^{249}$ Both governments nevertheless fail to provide an adequate justification of public security compatible with the right of establishment, including the right to acquire and use immovable property. ${ }^{250}$ At this stage, it can already be concluded that public security cannot justify the discriminatory Hungarian legislation because the whole territory of a nation cannot be regarded as being of military importance. This justification is only available to certain pieces of land where real and serious risks to the military interest of the country are at stake.

Contrastingly, the justification of public policy might be relevant here. Article 27 of Directive 2004/38 specifies that this potential justification must comply with the principle of proportionality and be based exclusively on the personal conduct of the individual concerned. This last condition entails a genuine, present and sufficiently serious threat affecting one of the fundamental interests of society. Justifications that are isolated from the particulars of the case or that rely on considerations of general prevention shall not be accepted.'251

The Hungarian parliament passed the Act LV of 1994 with the objectives of moving from the original planned economy towards a market economy. ${ }^{252}$ The Accession negotiations provide further inside on the real reasoning behind the willingness to prohibit any purchase of agricultural land by foreigners. The government asserted the necessity of safeguarding their socio-economic agricultural structure from shocks arising from the differences in land prices and incomes in comparison with OMS. In Hungary, the authorities also raised the issue of the unfinished process of privatization and restitution of agricultural land to former owners, which is also reflected in the preamble of the Act LV of 1994. ${ }^{253}$

249 C-423/98 Re Albore [2000] ECR I-5965, paras. 12 \&18; C-305/87 Commission EC v Greece (Border Regions) [1989] ECR I-1461, para.3.

250 C-423/98 Re Albore [2000] ECR I-5965, para. 24; C-305/87 Commission EC v Greece (Border Regions) [1989] ECR I-1461, para. 29.

251 Directive 2004/38 EC of the European Parliament and of the Council of 29 April 2004 on the rights of citizens of the Union and their family members to move and reside freely within the territory of the Member States amending Regulation (EEC) No 1612/68 and repealing Directive 64/221/EEC, 68/360/ EEC, 72/194/EEC, 73/148/EEC, 75/34/EEC, 75/35/EEC, 90/364/EEC, 90/365/EEC and 93/96/EEC.

252 Preamble of the Hungarian Act.

253 Hodgson et al. 1999, p. 23; [3.2.1.2]. 
However, the real aims pursued in banning foreign land ownership seem to be more politically and socially oriented.254 The Hungarians fear a reduction of the territory as a consequence of extensive purchases of large amounts of land by foreigners. Influenced by the rural-nationalist ideology, the population believes that land belongs to them and should be protected from foreigners, seen as enemies from the wellbeing of the nation state. ${ }^{255}$ It can therefore be deduced that the actual purpose of the ban is to prohibit in any way the purchase of agricultural land by anyone not possessing the Hungarian nationality. ${ }^{256}$ Under those circumstances, public policy cannot be invoked as justifying the Act LV of 1994.

\subsubsection{Public interest requirement}

In Uwe Kay Festersen, the CJEU argues that facilitating the preferential appropriation of land by persons wishing to farm pursues a public interest objective. ${ }^{257}$ In Denmark, agricultural land is recognized as a limited natural resource. By imposing a residence requirement, the Danish government wishes to control the acquisition of agricultural land. ${ }^{25}$ However, this argument is irrelevant to the Polish situation because land cannot be considered as a limited natural resource.

Agriculture is one of the major components of the Polish economy. The agricultural society is based upon the concept of family farms. ${ }^{259}$ Article 23 of the Constitution helps to preserve the traditional forms of farming, where the owners predominantly occupy and farm their small plots of land. The Polish agricultural policy follows specific objectives, aiming to preserve a permanent agricultural community, to encourage reasonable use of available land and to protect the natural environment. ${ }^{260}$ During the Accession negotiations, the Polish government further defended a need to safeguard the socioeconomic conditions for agricultural activities within and following the introduction of the Internal Market. The authorities fear extensive acquisition of large portions of rural land by foreign citizens or companies, giving rise to land scarcity and a loss of territorial sovereignty. Following a town and country planning, the CJEU has successively declared

\footnotetext{
254 [3.2.2.].

255 lbid.

256 Section 7 of the Hungarian Act.

257 C-370/05 Uwe Kay Festersen [2007] ECR I-01129.

258 Ibid., para. 25; Jasmina Zwierz, p. 25.

259 Article 23 of the Polish Constitution.

260 Jasmina Zwierz, p. 25-26; [3.1. \& 3.2.1]
} 
that such social objectives are compatible with EU law. ${ }^{261}$

However, in his Opinion in the Flemish Decree case, AG Mazak clarifies that the preservation of the Flemish nature of the population cannot be regarded as an overriding reason in the public interest. ${ }^{262}$ Concerning the Polish situation, this argument is of great relevance because the 'unofficial' and actual reasons are associated with political and social aspiration. The rural-nationalist ideology and the role of history have played a central role in the Polish landscape. For many years, the myth of the 'German return' has been circulating in Poland, which creates a strong feeling against foreign land ownership. Thanks to EU expansion, Germans are able to acquire large amounts of land and those acquisitions are seen as a threat to the nation. ${ }^{263}$ Following the reasoning of AG Mazak, the Polish objectives cannot therefore be regarded as an overriding reason in the public interest.

\subsection{Principle of Proportionality}

The principle of proportionality is based on the assumption that public authorities may not impose obligations on their citizens, excepting when they are strictly necessary for or proportionate to the aim that is sought. The test requires balancing various conflicting interests - e.g. the proper functioning of the internal market against public safety or protection of the environment. ${ }^{264}$

Concerning land-related issues, the CJEU has shown some sensitivity towards great national value. In Schmidberger, the Court concurs that the restrictions in Community trade are proportionate in light of such fundamental rights as freedom of expression and assembly.265 However, the CJEU is much stricter when state measures are to be justified on the ground of public policy. As a general rule, rules strictly restricting foreigners' free movement are discriminatory and not proportionate, except to the extent that such provisions will lead to a genuine and sufficiently serious threat to the fundamental

261 C-370/05 Uwe Kay Festersen [2007] ECR I-01129, paras. 27-28; Joined cases (C-515/99, C-519/99 to C-524/99 and C-526/99 to C-540/99) Reisch and others v Burgermeister der landeshauptstadt Salzburg, [2002] ECR I-2157, para. 34; C-302/97 Klaus Konle v Austrian Republic, [1999] ECR I-03099, para. 40; C-452/01 Margarethe Ospelt and Schlossle Weissenberg v Austrian Government, [2003] I-o9743, para. 38-39.

262 Opinion of Advocate General Mazak delivered on 4 October 2012 (Joined cases C-197/11 \& C-203/11), para. 34

263 Tesser 2004, p. 218.

264 Jasmina Zwierz, p. 23.

265 C-112/oo Eugen Schmidberger Internationale Transporte und Planzüge v Republik Osterreich [2003] ECR I-05659, para. 93. 
interests of society. ${ }^{266}$ As previously mentioned, the Hungarian Act cannot be justified on the ground of public policy, and consequently the proportionality test is also not fulfilled.

In Gebhard, the CJEU develops the proportionality test to be followed in situations where national measures are indirectly discriminating on the European legal order.

'(..) National measures must be suitable for securing the attainment of the objective which they pursue; and they must not go beyond what is necessary in order to attain it. ${ }^{267}$

In descending order of intrusiveness, MS have three levels to control the acquisition of land by foreigners in their territories: prior authorization, advance declaration and retrospective declaration. ${ }^{268}$ In Konle, the CJEU declares that a prior administrative authorization procedure, such as that at issue, cannot be based on conditions capable of fulfilling the proportionality test. This scheme is subject to a high discretion of the administrative authorities and renders therefore the free movement rights illusory.

On the contrary, the Court confirms in Reisch that a system of prior declaration is compatible with EU law and can more appropriately achieve the aims pursued by the Austrian legislation. ${ }^{269}$ Unlike supervision procedures, this scheme has the advantage of providing legal certainty to the acquirer of a title. The CJEU further specifies that the formality of prior notification is seen as a step, which is additional to the criminal sanctions and/or the action of annulment of the sale. ${ }^{270}$

Under Polish law, sales to foreigners are subject to a specific procedure whereby the Ministry of Interior and Administration and the Ministry of Agriculture and Rural Development are empowered to lodge an objection in order to restrain sales.271 This procedure not only applies to natural persons without Polish citizenship but also to legal persons. ${ }^{272}$ Following the Court's reasoning in Reisch, Konle and in its Flemish Decree judgment, the Polish system of permit cannot be compatible with EU law and must

\footnotetext{
266 Jasmina Zwierz, p. 24; C-423/98 Re Albore [2000] ECR I-5965, para 22.

267 C-55/94 Reinhard Gebhard v Consiglio dell'Ordine degli Avvocatie Procuratori di Milano ECR I-04165, para. 37.

268 Sparkes 2007, p. 87.

269 Joined cases (C-515/99, C-519/99 to C-524/99 and C-526/99 to C-540/99) Reisch and others v

Burgermeister der landeshauptstadt Salzburg, [2002] ECR I-2157, para. 35.

270 lbid., para 36.

271 Jasmina Zwierz, p. 12.

272 Article 1(2) of the Act.
} 
be replaced by an appropriate notification system, which will not remove the effective pursuit of the aims of the Polish measures.

\section{Conclusion}

The analysis of the Act of 24 March 1920 and the Act LV of 1994 has shown that Poland and Hungary are far from fulfilling the second condition of the Copenhagen criteria: the existence of a functioning [land] market economy opened to EU MS nationals. In 2009, the Hungarian government requested from the Commission a prolongation of three years from its traditional transitional period. The authorities argued that opening its land market would have disastrous economic consequences. It can nevertheless be noticed that the real reasons behind this prolongation, which are also relevant to the transitional period granted to Poland, are more closely related to political and social aspiration. Both Member States have developed strong negative feelings against foreigners from both inside and outside the EU.

On the one hand, the law of each Member State governs the system of property ownership within the European Union. This concept is closely connected to the traditions and customs of society. On the other hand, even though strongly nationalized, national measures cannot constitute a restriction to the functioning of fundamental freedoms. Community law through the free movement of capital, persons and services affects the domestic system of property law. Traditionally, the private international law concept of lex rei sitae solves conflict of property laws. However, state accession into the EU dismisses the influence of private international law on property matters. Although national private international law applies to all cases relating to national situations, rules regulating the Internal Market are relevant to legal situations involving a cross-border element. In such cases, EU law takes precedence over national law.

It has been established throughout this paper that the free movement of establishment also affects the acquisition of agricultural land. Even though such purchases always involve a capital transaction, the rights enjoyed by EU citizens to establish themselves cannot be neglected. Any restrictions on property matters will hinder the exercising of this right to movement. Having said that, it is surprising to notice that the transitional periods granted to Hungary and Poland are only dealt with in the context of capital. Indeed, the Polish permit system and the Hungarian ban on the acquisition of agricultural land by foreigners may remain in force until 2014 (Hungary) and 2016 (Poland). During this period of time, those restrictions are tolerated by the European legal order in accordance with the free movement of capital. 
However, this situation cannot be carried on anymore. The Internal Market lays down the legal basis on which any national rules that hinder cross-border trade are against EU law. For too long, the Act LV of 1994 and the Act of 21 March 1920 have directly or indirectly infringed upon those European rules. In Gebhard, the CJEU nevertheless suggests that any discriminatory legislation may be allowed, provided that they pursue an objective in the public interest. Direct discrimination may also be tolerated on grounds of public policy, public security or public health. Following the analysis of this paper, it can be concluded that both Polish and Hungarian Acts cannot be justified either on grounds of public policy or in the public interest. In Hungary, the Act LV of 1994 does not pursue the objective of preventing a genuine, present and sufficiently serious threat affecting one of the fundamental interests of society. Its main purpose is to ban the purchase of agricultural land by anyone not having the Hungarian nationality. Within this way of reasoning, the proportionality test also cannot be fulfilled. In Poland, the Polish legislation is less intrusive and instead of banning such purchases, the authorities apply a prior authorization procedure. It nevertheless cannot be justified by the public interest requirement because the real reasons behind their actions relate more to a strong feeling against foreigners than to have resulted from accepted socio-economic purposes such as town and country planning. Moreover, the CJEU specifies in several cases that a prior authorization system cannot be accepted as complying with EU law. Consequently, it can be argued that the Polish and Hungarian Acts are infringing upon EU law and should be interpreted as inapplicable.

In addition to breaching European law, those transitional restrictions do not economically make sense. Several authors agree that direct foreign investment is beneficial to the Polish and Hungarian economies. During the Accession negotiations, both governments claimed that opening their land market to EU MS nations would result in land scarcity. However, this argument can be refuted easily by pointing out the present cheapness of land. If land were actually scarce, the demand would be greater and consequently the price would have arisen more extensively. Furthermore, statistical data have shown that land is not scarce in Poland and Hungary. The actual difficulty of the current situation is the remaining status quo. Even though privatization has helped to improve their economic competiveness, the demand and supply sides remain low. Poland and Hungary are desperately in need of direct foreign investment in order to boost their economies.

When Hungary and Poland turned their interest towards joining the European Union, they knew beforehand for which 'contracts' they were signing up. By saying that, both Member States deliberately had the choice and the knowledge of what conditions they 
had to meet in order to become fully active Member States. One of them was to open their land market to EU citizens and to remove any restrictions on them. The European Union is not only about gaining collective benefits; but also about making concessions in order to work together in harmony. After several years of transition, it is time for Hungary and Poland to accept their choice and stand forward. The European Union is an amazing adventure where all Member States benefit from one way or another. 


\section{Annex}

Table 1 Legal restrictions on the acquisition of agricultural land in the NMS

\begin{tabular}{|c|c|c|c|c|}
\hline & Expiry date & $\begin{array}{l}\text { Can EU citizens buy } \\
\text { agricultural land despite } \\
\text { the restrictions? }\end{array}$ & $\begin{array}{l}\text { Can a legal } \\
\text { entity buy } \\
\text { agricultural } \\
\text { land? }\end{array}$ & $\begin{array}{l}\text { Can a legal entity that is } \\
\text { registered in the country } \\
\text { but owned by foreigners } \\
\text { buy agricultural land? }\end{array}$ \\
\hline Poland & $30 / 04 / 2016$ & $\begin{array}{l}\rightarrow \text { Plots <iha not located in } \\
\text { border zones } \\
\text { YES, if } \\
\text { - married to a Polish } \\
\text { citizen } \\
\text { - residing in the country } \\
\text { for at least } 5 \text { years } \\
\rightarrow \text { Other plots } \\
\text { YES, if } \\
\text { - married to a Polish } \\
\text { citizen } \\
\text { - she/he has been residing } \\
\text { and farming in the } \\
\text { country for at least } 3 \\
\text { years (then the plot that } \\
\text { she/he has been renting } \\
\text { can be bought) }\end{array}$ & YES & $\begin{array}{l}\text { YES, if minority of shares is } \\
\text { owned by foreigners }\end{array}$ \\
\hline Hungary & $30 / 04 / 2014$ & $\begin{array}{l}\text { YES, if } \\
\text { - married to a Hungarian } \\
\text { partner } \\
\text { - residing and farming in } \\
\text { the country for at least } 3 \\
\text { years (then the plot she/ } \\
\text { he has been renting can } \\
\text { be bought) }\end{array}$ & NO & NO \\
\hline $\begin{array}{l}\text { Czech } \\
\text { Republic }\end{array}$ & $30 / 04 / 2011$ & $\begin{array}{l}\text { YES, if } \\
\text { - married with Czech } \\
\text { partner } \\
\text { - she/he has been staying } \\
\text { and farming in the } \\
\text { country for at least } 3 \\
\text { years, then she/he can } \\
\text { buy any parcel in the } \\
\text { country }\end{array}$ & YES & $\begin{array}{l}\text { YES, if minority of shares is } \\
\text { owned by foreigners }\end{array}$ \\
\hline
\end{tabular}




\begin{tabular}{|c|c|c|c|c|}
\hline Estonia & $30 / 04 / 2011$ & $\begin{array}{l}\rightarrow \text { Plots < 10ha: } \\
\text { YES. } \\
\text { No additional conditions } \\
\text { have to be fulfilled } \\
\rightarrow \text { Plots > } 10 \text { ha } \\
\text { YES, if } \\
\text { - married to an Estonian } \\
\text { partner } \\
\text { - residing and farming in } \\
\text { the country for at least } 3 \\
\text { years (then the plot that } \\
\text { she/he has been renting } \\
\text { can be bought) }\end{array}$ & YES & YES \\
\hline Latvia & $30 / 04 / 2014$ & $\begin{array}{l}\text { YES, if } \\
\text { - married to a Latvian } \\
\text { partner but only as a } \\
\text { co-owner } \\
\text { - residing and farming in } \\
\text { the country for at least } 3 \\
\text { years (then the plot that } \\
\text { she/he has been renting } \\
\text { can be bought) }\end{array}$ & YES & $\begin{array}{l}\text { YES, if minority of shares is } \\
\text { owned by foreigners }\end{array}$ \\
\hline Lithuania & $30 / 04 / 2014$ & $\begin{array}{l}\text { YES, if } \\
\text { - married to a Lithuanian } \\
\text { partner } \\
\text { - residing and farming in } \\
\text { the country for at least } 3 \\
\text { years (then the plot that } \\
\text { she/he has been renting } \\
\text { can be bought) }\end{array}$ & YES & YES \\
\hline Slovakia & $30 / 04 / 2014$ & $\begin{array}{l}\text { YES, if } \\
\text { - married to a Slovakian } \\
\text { partner } \\
\text { - residing and farming in } \\
\text { the country for at least } 3 \\
\text { years (then the plot that } \\
\text { she/he has been renting } \\
\text { can be bought) }\end{array}$ & YES & YES \\
\hline
\end{tabular}

\section{Sources:}

This table is extracted from Swinnen and Vranken 2009, p.5 


\section{Bibliography}

\section{Primary Sources:}

$\operatorname{COM}(2010 / 792 / E U)$

- Commission Decision of 20 December 2010, extending the transitional period concerning the acquisition of agricultural land in Hungary (Text with EEA relevance) (2010/792/EU) Retrieved from http://eur-lex.europa.eu/LexUriServ/LexUriServ.do?uri=OJ:L:2010:336:0060:0061:EN:PDF

Act LV of 1994 on Arable Land (English version)

- Retrieved from http://faolex.fao.org/docs/html/hun6866E.htm

Act of 24 March 1920 on the acquisition of immovable properties by foreigners (English version)

- Retrieved from http://www.polishlaw.com.pl/pdf/act17b_new.pdf

Annex $\mathrm{X}$ of the Act of Accession (Hungary)

- Retrieved from http://ec.europa.eu/enlargement/archives/pdf/enlargement_process/future_prospects/ negotiations/eu10_bulgaria_romania/treaty_2003/en/aa00037_reo3_en.pdf

Annex XII of the Act of Accession (Poland)

- Retrieved from http://www.europarl.europa.eu/enlargement_new/treaty/default_en.htm

Accession Agreement of April 2003

- Retrieved from http://www.europarl.europa.eu/enlargement_new/treaty/default_en.htm

Europe Agreement (Hungary)

- Europe Agreement establishing an association between the European Communities and the Member States, of the one part, and the Republic of Poland, of the other part. Retrieved from http://wits.worldbank.org/GPTAD/PDF/archive/EC-Hungary.pdf

Europe Agreement (Poland)

- Europe Agreement establishing an association between the European Communities and the Member States, of the one part, and the Republic of Poland, on the other part. Retrieved from http://wits.worldbank.org/GPTAD/PDF/archive/EC-Poland.pdf

Hungarian Constitution (English version)

- Retrieved from http://www2.ohchr.org/english/bodies/cescr/docs/E.C.12.HUN.3-Annex2.pdf

Polish Constitution (English version)

- Retrieved from http://www.sejm.gov.pl/prawo/konst/angielski/kon1.htm 


\section{Secondary Sources:}

\section{Akkermans 2010}

- Bram Akkermans; The European Union development of European property law; [working paper]. Maastricht European Private Law Institute, 2010. Retrieved from http://papers.ssrn.com/sol3/papers.cfm?abstract_id $=1694404$

Akkermans and Ramaekers 2010

- Bram Akkermans and Eveline Ramaekers; 'Article 345 TFEU (ex Article 295 EC), Its Meanings and Interpretations.' European Law Journal Vo. 16, No. 3 2010, pp. 292-314

Albi 2007

- Anneli Albi; 'Supremacy of EC law in the New Member States: bringing parliaments into the Equation of 'Cooperative constitutionalism". European Constitutional Law Review Vol.3, Issue 12007 , pp. 25-67

Burger 2006

- Anna Burger; 'Why is the issue of land ownership still of major concern in East Central European (ECE) transitional countries and particularly in Hungary?' Elsevier Ltd., Land Use Policy Vol. 23, Issue 4 2006, pp.571-579

\section{Dadak 2004}

- Casimir Dadak; 'The case for foreign ownership of farmland in Poland' Cato Journal Vol. 24 , No. 3 2004, pp. 227-292

\section{Grabbe 2002}

- Heather Grabbe; 'European Union Conditionality and the Acquis Communautaire.' International Political Science Review Vol. 23, No. 3 2002, pp. 249-268

Graig and De Búrca 2011

- Paul Graig \& Gráinne De Búrca; EU law: text, cases and materials. [5 ${ }^{\text {th }}$ ed.], Oxford [etc.]: Oxford University Press, 2011

Hodgson et al. 1999

- Stephen Hodgson et al.; Land ownership and foreigners: a comparative analysis of regulatory approaches to the acquisition and use of land by foreigners. FAO Legal Papers Online, 1999

Kwiecien 2005

- Roman Kwiecien; 'The primacy of European Union law over national law under the Constitutional Treaty.' German Law Journal Vol. 6, No.11 2005, pp. 1479-1496

Marks-Bielska 2012

- Renata Marks-Bielska; 'Factors shaping the agricultural land market in Poland.' Elsevier Ltd., Land Use Policy Vol. 30, 2013, P 791-799 


\section{Marktler 2006}

- Tanja Marktler; 'The power of the Copenhagen criteria.' Croatian Yearbook of European Law and Policy Vol. 2, 2006, pp. 343-363

Sparkes 2007

- Peter Sparkes; European Land Law. Oxford \& Portland: Hart Publishing, 2007

Tesser 2004

- Lynn M. Tesser; 'Communist and post-communist studies: East-Central Europe's new security concern - foreign land ownership.' Elsevier Ltd., Land Use Policy Vol. 37, Issue 2 2004, p.213-239

Van Erp 2006

- Sjef van Erp; European and national property law: osmosis or growing antagonism? Groningen: Europa law Publishing, 2006

Van Erp \& Akkermans 2012

- Sjef van Erp and Bram Akkermans; Cases, materials and text on property law. Oxford \& Portland: Hart Publishing, 2012

\section{Weisman 1980}

- Joshua Wiesman; 'Restrictions on the acquisition of land by aliens.' The American Journal of Comparative Law Vol.28, Issue 1, 1980, pp. 39-66

Williamson et al. 2002

- Ian P. Williamson et al.; 'The role of land administration in the accession of central European countries to the European Union.' Elsevier Ltd., Land Use Policy Vol.19, Issue 1, 2002, pp. 29-46

Jasmina Zwierz

- Magdalena Jasmina Zwierz under the supervision of Prof. dr. J.H.M. Van Erp \& Dr. Bram Akkermans; The acquisition of real estate in Poland by nationals of other Member States. Maastricht University

\section{Internet Sources:}

\section{Akkermans 2010}

- Bram Akkermans; The European Union development of European property law; [working paper]. Maastricht European Private Law Institute, 2010. Retrieved from http://papers.ssrn.com/sol3/papers.cfm?abstract_id $=1694404$

Akkermans and Ramaekers 2012

- Bram Akkermans \& Eveline Ramaekers; Lex rei sitae in perspective: national developments of a common rule?; [working paper]. Maastricht European Private Law Institute, 2012. Retrieved from http://papers.ssrn.com/sol/3/papers.cfm?abstract_id $=2063494$ 


\section{Burger 2005}

- Anna Burger; The issue of land ownership and rural nationalism in the East Central European/ECE/countries. A case study of Hungary; [2005 International Congress, Denmark 23-27]. Institute of Economics of the Hungarian Academy of Sciences, 2005. Retrieved from http://econpapers.repec.org/paper/agseaaeo5/24554.htm

Ciaian et al. 2012

- Ciaian et al.; Sales Market Regulations for Agricultural Land in EU Member States and Candidate Countries; [working paper]. Factor Markets, 2012. Retrieved from http://www.google.nl/url?sa=t\&rct=j\&q=\&esrc $=s \&$ source $=w e b \& c d=2 \& v e d=0 C E A Q F j A B \& u r$ $I=h t t p \% 3 A \% 2 F \% 2 F w w w . c e p s . e u \% 2 F c e p s \% 2 F d l d \% 2 F 6621 \% 2 F p d f \& e i=G y z d U d a X L s e u 7 A b 1 h o E Y$ \&usg=AFOjCNEyUOjn6z8qM870cUCNpdhesrgRw\&sig2=6RocJaM2OMK2WUbIMmHorQ

Community Acquis

- Retrieved from http://europa.eu/legislation_summaries/glossary/community_acquis_en.htm

Europe Agreement

- Retrieved from http://ec.europa.eu/enlargement/policy/glossary/terms/europe-agreement_en.htm Europa - Press releases (IP/10/1750)

- 'Commission grants Hungary extension of transitional period for the acquisition of agricultural land.' Brussels, 20 December 2010. Retrieved from

http://europa.eu/rapid/press-release_IP-10-1750_en.htm

Europa - Press releases (MEMO/11/244)

- 'Frequently asked questions: Extension of transitional periods for the acquisition of agricultural land.' Brussels, 14 April 2011. Retrieved from

http://europa.eu/rapid/press-release_MEMO-11-244_en.htm?locale=fr

Gardner 1993

- Anthony Gardner; 'European community law and real property.' 18 International legal practitioner, Brussels, 1993, pp.75-79, Retrieved from

http://heinonline.org/HOL/Page?handle=hein.journals/ilp18\&div=27\&g_sent=1\&collection=journals

Giovarelli and Bledsoe 2001

- Renee Giovarelli and David Bledsoe; Land reform in Eastern Europe: Western CIS, Transcaucuses, Balkans and EU accession countries. FAO Corporate Document Repository, Seattle, October 2001

Retrieved from http://www.fao.org/docrep/o07/AD878E/AD878Eo6.htm 


\section{Mazak 2012}

- Opinion of Advocate General Mazak delivered on 4 October 2012 (Joined cases C-197/11 and C-203/11, Eric Libert and others v Government flamand and All projects \& developments $N V$ and others $v$ Vlaams Regering, [2013] not yet published) Retrieved from $h$ ttp://curia.europa.eu/juris/document/document.jsf?text $=\&$ docid $=1280$ $42 \&$ pagelnde $=0 \&$ doclang $=E N \&$ mode $=I s t \&$ dir $=\& o c c=$ first $\&$ part $=1 \& c i d=140947$

Mihaljek 2005

- Dubravko Mihaljek; Free movement of capital, the real estate market and tourism: a blessing or a curse for Croatia on its way to the European Union? 2005, p.185-228. Retrieved from http://fes.hr/E-books/pdf/Croatian\%20accession\%20to\%20EU_3td/o8_o.pdf

Repa 2006

- Jan Repa; 'Polish nationalism resurgent' in BBC News Retrieved from $h t t p: / / n e w s . b b c . c o . u k / 2 / h i / e u r o p e / 4754079 . s t m$

\section{Schmid 2005}

- Christoph U.Scmid and Christian Hertel; Real property law and procedure in the European Union: general report (final version). European University Institute (EUI) Florence/European Private Law Forum Deutsches Notarinstitut (DNotl) Würzburg, 2005. Retrieved from http://www.eui.eu/Documents/DepartmentsCentres/Law/ResearchTeaching/ ResearchThemes/EuropeanPrivateLaw/RealPropertyProject/GeneralReport.pdf

\section{Swinnen \& Vranken 2009}

- Johan F.M. Swinnen \& Liesbet Vranken; Land and EU Accession: review of the Transitional Restrictions by New Member States on the acquisition of agricultural real estate. European Community, Centre for European Policy Studies (CEPS), Brussels, 2009 Retrieved from http://ec.europa.eu/internal_market/capital/docs/study_en.pdf

Raugalaite 2012

- Jone Raugalaire under the supervision of Per Lunde; The acquisition of agricultural land in Lithuania by foreigners: Case Study of Lithuania. Aalborg Universitet, 10th Semester, 2012 Retrieved from http://projekter.aau.dk/projekter/files/68733681/Thesis311.pdf

Wallis 2011

- Diana Wallis and Sara Allanson; European Property: rights and wrongs. Diana Wallis: Conexio Public Relations, 2011. Retrieved from http://www.google.nl/url?s $a=t \& r c t=j \& q=\&$ es $r c=s \&$ source $=w e b \& c d=1 \&$ ved $=O C D Q Q$ FjAA\&url $=$ http\%3A\%2F\%2Fdianawallismep.org.uk\%2Fen\%2Fdocument $\% 2 F e u r o p e a n-p r o p e r t y-r i g h t s$-and-wrongs.pdf\&ei=2ZPdUbagEPKh7AaRgIGYDA\&usg=AFOjCNG 1ASljq1FU_GWUXFIIRIqOYYDJkw\&sig2=ywGgVm4u8Y-VDOZssi_uog\&bvm $=b v .48705608$,d.d2k 